\title{
Experimental evaluation of the interaction between strength concrete block walls under vertical loads
}

\section{Avaliação experimental da interação entre paredes de blocos de concreto de alta resistência sob ações verticais}

L. O. CASTRO a

lucascastro.ecivil@gmail.com

R. C. S. S. ALVARENGA a rcassia.alvarenga@gmail.com

R. M. SILVA b

roberto@dees.ufmg.br

J. C. L. RIBEIRO a

jcarlos.ribeiro@ufv.br

\begin{abstract}
This paper aims to evaluate the interaction between structural masonry walls made of high performance concrete blocks, under vertical loads. Two $\mathrm{H}$-shaped flanged wall series, all full scale and using direct bond, have been analyzed experimentally. In one series, three flanged-walls were built with the central wall (web) supported and, in the other one, three specimens were built without any support at the central web. The load was applied on the central wall and vertical displacements were measured by means of displacement transducers located at eighteen points in the wall-assemblages. The results showed that the estimated load values for the flanges were close to those supported by the walls without central support, where $100 \%$ of the load transfer to the flanges occur. The average transfer load rate calculated based on the deformation ratio in the upper and lower section of the flanged-walls, with the central web support, were $37.65 \%$ and $77.30 \%$, respectively, showing that there is load transfer from the central wall (web) toward the flanges, particularly in the lower part of the flanged walls. Thus, there is indication that the distribution of vertical loads may be considered for projects of buildings for service load, such as in the method of isolated walls group. For estimation of the failure load, the method that considers the walls acting independently showed better results, due to the fact that failure started at the top of the central wall, where there is no effect of load distribution from the adjacent walls.
\end{abstract}

Keywords: high stre performance block, structural masonry, flanged walls, wall interaction.

\section{Resumo}

Este trabalho tem como objetivo avaliar a interação entre paredes de alvenaria estrutural de blocos de concreto de alta resistência, sob ações verticais. Foram ensaiadas duas séries de paredes com flanges intertravadas, em formato "H" em escala real e com amarração direta, sendo uma série composta de três espécimes com a parede central (alma) apoiada e a outra série de três espécimes sem apoio na alma. A carga foi aplicada na parede central e através de transdutores de deslocamento foram monitorados os deslocamentos verticais em dezoito pontos do conjunto de paredes. Os resultados mostram que os valores de carga estimados para os flanges das paredes com apoio central foram próximos daqueles suportados pelos flanges das paredes sem apoio central, nas quais ocorrem 100\% de transferência de carga para os mesmos. As taxas de transferência médias, calculadas com base na relação de deformações no trecho superior e inferior para o conjunto de paredes com apoio central, foram de $37,65 \%$ e $77,30 \%$, respectivamente, mostrando que existe transferência de carga da parede central (alma) para os flanges, particularmente no trecho inferior do conjunto de paredes. Assim, há um indicativo de que a distribuição de forças verticais pode ser considerada em projetos de edifícios para cargas de serviço, como no método de grupo isolado de paredes. Com relação ao comportamento último das paredes com flanges com apoio na alma, a ruptura ocorre no topo da alma, local onde ainda não ocorre transferência de forças verticais entre paredes adjacentes, neste caso o método de paredes isoladas para a estimativa da carga de ruptura seria adequado.

Palavras-chave: blocos de alta resistência, alvenaria estrutural, paredes com flanges, interação entre paredes. 


\section{Introduction}

Historically, the improvement in concrete performance is evident due to the necessity of constructing increasingly tall buildings as well as meeting durability requisites. The use of mineral additives (active silica, calcined clay) and plasticizer additives, combined with a low water/cement ratio and high binder consumption enable the production of more resistant, less porous and less permeable concretes.

The interaction between walls has gained attention and need for investigation, particularly when high strength concrete blocks are used, as there are few papers and a lot of disparity about the subject. Some authors consider that walls work isolated while other admit an interaction between adjacent walls, that is, a load transmission from a more loaded to a less loaded wall, when there is a binding between them.

Some international norms, such as the American ACI/ASCE/TMS [1] and the Eurocode [2], don't usually allow considering interaction between walls in the vertical load distribution method. In Brazil, the ABNT NBR 15961-1 [3] norm allows considering interaction between walls as long as the shear strength limits at the wall interface are respected. This consideration is a result of some studies, for instance Capuzzo Neto (2000) [4], Andolfato (2006) [5] and Oliveira (2014) [6], who have researched interconnected walls build from ceramic blocks or concrete.

The clamping of the units in a group of walls built with direct bonding enables the distribution of vertical and lateral loads along the length and height of the walls with masonry flanges. The interaction between walls with indirect bonding, on the other hand, occurs not due to the clamping of the units, but due to other elements that guarantee the transfer of forces.

In buildings with greater heights and interspaces, the behavior of wall intersections under vertical loading and the possible load transfer along these heights have significant influence in the results of wall strength and foundation loading.

The load distribution in six full scale $\mathrm{H}$-shaped wall specimen, built with direct bonding, was evaluated in order to verify the interaction between flanged and interconnected walls, built with high strength concrete blocks when submitted to vertical loads. It also aimed to investigate the load transfer amongst them. In addition, tests were performed in the blocks, prisms and for mortar characterization.

It is known in the field of masonry construction that the introduction of high strength concrete blocks is favorable due to its high structural performance and durability, as well as other satisfying characteristics. Another relevant aspect of this study is that it evaluates blocks with different proprieties from those presented in the references. Hence, the study of interaction between walls built with high strength concrete blocks can contribute to the understanding of the occurrence of stress standardization, whereas previous papers considered hollowed ceramic blocks or regular concrete blocks. Furthermore, this aspect affects directly the safety and costs of masonry projects.

\section{Mechanical proprieties of structural masonry}

\subsection{Compressive strength}

The compressive strength of the block is the highest contributor to the final strength of the masonry. However, the increase of strength in the block is not directly proportional to the increase of strength in the masonry. The explanation to this lies in the fact that when the strength in the block increases, there is an increase of its stiffness in relation to the mortar, therefore rising the difference between the lateral deformations on the block and the mortar. Moreover, since there is a restraint in movement between those due to adherence, greater lateral tensions arise in the block, which can accelerate the failure of the set.

The ABNT NBR 15961-1 [3] norm fixes the lower value for the compressive strength as being $1.5 \mathrm{MPa}$ and the greater value is limited to 0.7 times the characteristic strength specified to the block, in relation to the liquid area.

The European code EN 1996-1-1 (2005) [2] establishes the equation (2.1) to determine the characteristic compression strength of the masonry based on the strength of the block and the mortar.

$$
f_{k}=K f_{b}^{0,7} f_{m}^{0,3}
$$

\section{Where:}

$K$ is a coefficient related to the type of block material and the type of mortar;

$f_{b}$ is the average compression strength of the unit, in relation to the gross area;

$f_{k}$ is the average compression strength of the masonry, in relation to the gross area;

$f_{m}$ is the average compressive strength of the mortar.

\subsection{Elasticity modulus}

The masonry elasticity modulus is found in the stress-strain graph drawn from the compressive test in order to evaluate and quantify the deformation that occurs during the test. The elasticity modulus as well as the Poisson ratio are important characteristics that regard not only the masonry deformation but also its failure mechanisms.

The ABNT NBR 15961-2 [7] and ABNT NBR 8949 [8] norms describe testing methods to obtain the elasticity modulus for prisms and masonry. However, there are no defined testing methodology to determine the elasticity modulus and Poisson ratio for concrete blocks.

According to Mahammad (2007) [9], the elasticity modulus of masonry elements can be obtained from the stress-strain graph, for a stress between $40 \%$ and $70 \%$ of the failure load of the secant modulus or through a stress of $30 \%$ of the initial tangent modulus. This happens because the elements (prisms and walls) have linear behavior within this interval. This method is similar to what is recommended by the ACI 530-02/ ASCE 5-02/ TMS 402-02 [1] norm, in which the initial interval of the stressstrain curve is negligible and the secant value between 0,05 $f_{m}^{\prime}$ and $0,33 f_{m}^{\prime}$ is used, where $f_{m}^{\prime}$ is the ultimate compression strength of the masonry.

In the absence of testing, equations presented in concrete norms may be used to estimate the elasticity modulus of the concrete block. The CEB - FIB Mode Code (1990) [10] defines 


\section{Figure 1 - Dimensions of flanged walls on site. $260 \mathrm{~cm}$ height walls | Heights in cm}
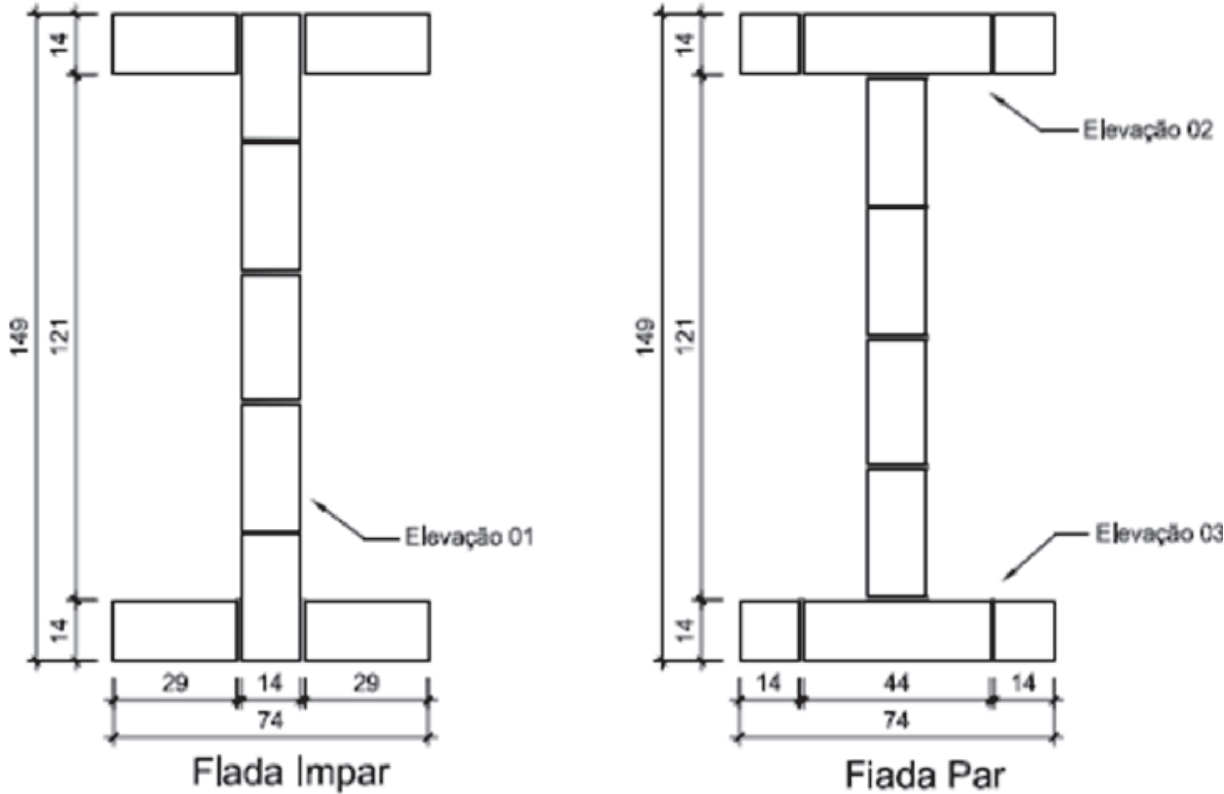

that the mlasticity Modulus can be obtained by the equation (2.2).

$$
E_{b}=2,5 \times 10^{4} \times\left(\frac{f_{b}}{10}\right)^{0,33}
$$

where:

$E_{b}$ is the block average elasticity modulus, in $\mathrm{MPa}$, in relation to the block liquid area;

$f_{b}$ is the block average compressive strength, in MPa, in relation to the block liquid.

The Equation (2.3) is suggested by the $\mathrm{ACl}$ - Building Code 318 [11] norm, which adopts concrete with specific weight between $1442 \mathrm{~kg} / \mathrm{m}^{3}$ and $2483 \mathrm{~kg} / \mathrm{m}^{3}$. As for the Poisson ratio, the reference value of 0.20 is used, as it is the Poisson ratio for the concrete.

$$
E_{b}=0,0428 f_{b}^{0,5} w_{b}^{1,5}
$$

\section{where:}

$E_{b}$ is the block average elasticity modulus, in $\mathrm{MPa}$, in relation to the block liquid are;

$f_{b}$ is the block average compressive strength, in MPa, in relation to the block liquid area;

$w_{b}$ is the unitary specific weight of the block, in $\mathrm{kg} / \mathrm{m}^{3}$.

To determine the elasticity modulus to the masonry, the norm ABNT NBR 15961-1 [3] establishes the value of $800 \mathrm{xf}_{\mathrm{pk}}$, where $\mathrm{f}_{\mathrm{pk}}$ is the specific strength of the prisms. Gomes (1983, apud CARVALHO, 2007) [12] studied theoretically the basic elastic parameters of masonry walls submitted to simple compression, analyzing and comparing the results with those obtained experimentally. Considering that the wall thickness is significantly lower than the other wall dimensions, in the plane state of stress, for unreinforced walls and assuming complete adherence between mortar and blocks with both comping the Hooke's law, the Equation (2.4) is obtained:

$$
E_{p a}=\frac{1}{\frac{(1-\delta)}{E_{a}}+\frac{\delta}{E_{b}}} \text {, with } \delta=\frac{h_{b}}{H}
$$

where:

$E_{p a}$ is the elasticity modulus of the wall, in MPa;

$E_{a}$ is the elasticity modulus of the mortar, in MPa.

$E_{b}^{a}$ is the elasticity modulus of the blocks, in MPa.

$h_{b}$ is the block height, in $\mathrm{cm}$.

$H$ is the masonry height, in $\mathrm{cm}$.

The equation (2.5) is used to estimate the elasticity modulus of the wall when the elasticity modulus of the block and the mortar are known. Dhanasekar (1985, apud MOHAMAD, 2007) [9] suggests a non-linear relationship to establish the elasticity modulus of the masonry in relation to its uniaxial compressive strength, in $\operatorname{MPa}\left(f_{c}\right)$.

$$
E_{p a}=1180 \times\left(f_{c}\right)^{0,83}
$$


$E_{p a}$ is the elasticity modulus of the wall, in $\mathrm{MPa}$, in relation to the gross area;

$f_{c}$ is the compressive strength of the masonry, in MPa, in relation to the gross area.

The equations presented in this topic to obtain the elasticity modulus of masonry are developed by different researches regarding several materials and will be compared with the experimental results in this study.

\section{Materials and experimental program}

Two series with flanged masonry walls in full scale were tested in this paper. The first series consisted of three "H" shaped specimens on site with supported central wall and flanges. The second series consisted of three " $\mathrm{H}$ " shaped specimens on site, in which the central wall had no support. Since the flanges were only supported in the second series, this allowed total load transfer to the flanges and therefore it was possible to compare the two series.

In both series, the vertical and the horizontal joints were filled with mortar, with one $\mathrm{cm}$ thickness and direct bonding was used. A $90 \mathrm{~cm}$ long steel plate was chosen for the uniform application of the load over the web, simulating the effect of a supporting row at the top of the wall. The steel plate applied the load over the three middle blocks of the central wall, ex- cluding the blocks that were directly attached to the flanges, Figure [7].

The use of a slab to apply the load on the wall would have been ideal for the experiment. However, it would be more complex, as the test were carried out in full scale.

\subsection{Geometry, construction of flanged walls and transportation}

Interlocked units were applied in the construction of the flanged walls. Special units of $44 \mathrm{~cm}$ length with three hollows were used for the clamping. The specimens were constructed under metallic framing and after the cure interval they were transported to the portico where they were tested. The dimensions (in centimeters) of these walls on site are shown in Figure [1].

The construction of the flanged walls were carried out in three steps according to recommendations of the ABNT NBR 8949:1985 [8] norm. On the first day, five rows were built and on the subsequent days, four rows were built each day. The first step of the masonry walls construction can be observed in Figure [2]. For each step, three prismatic mortar specimens were molded.

A rolling bridge transported the specimens to the testing location. In Figure [3], a flanged wall specimen being transported to the reaction portico is shown.

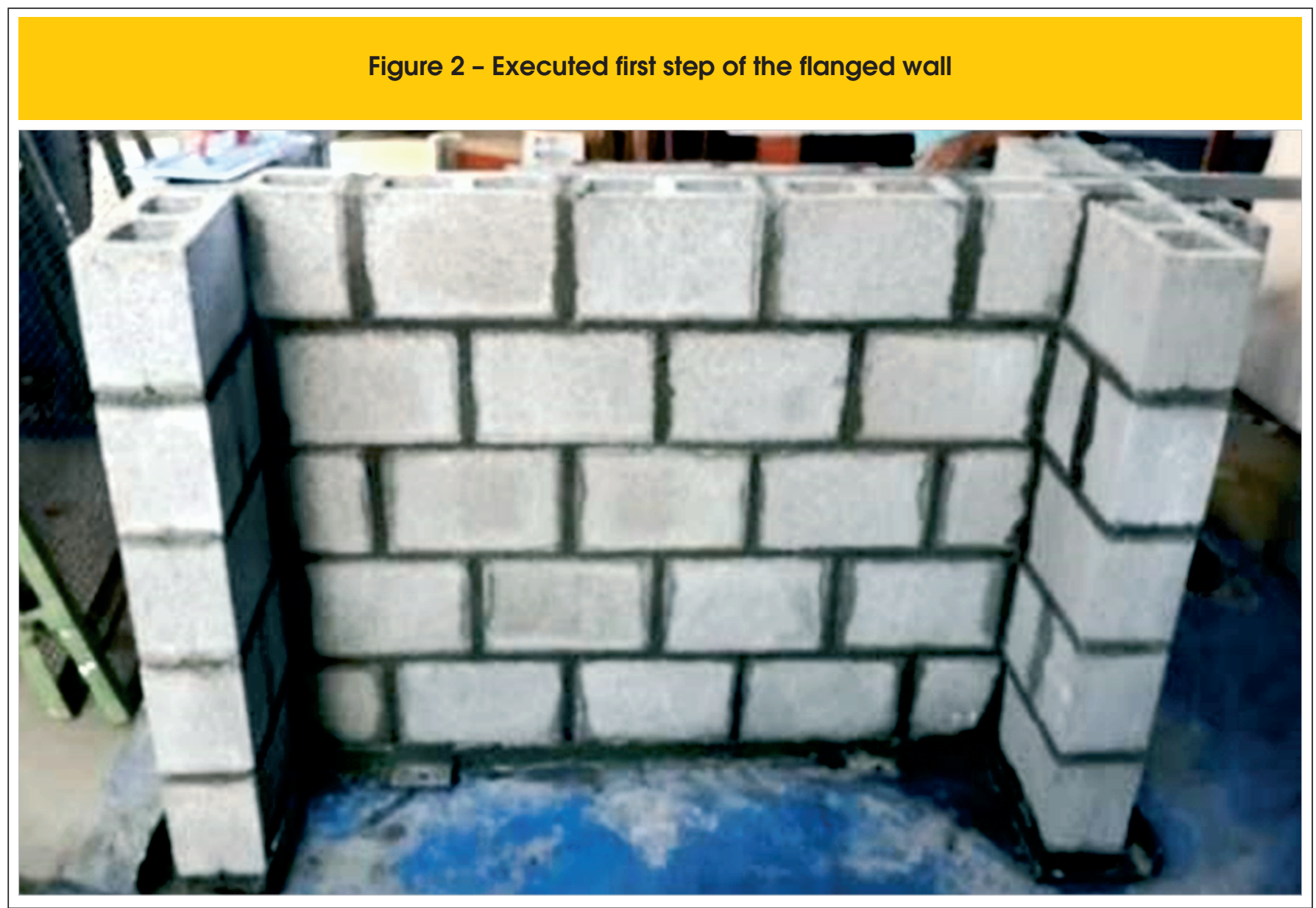




\section{Figure 3 - Executed flanged wall and its transportation to the reaction portico by rolling bridge}

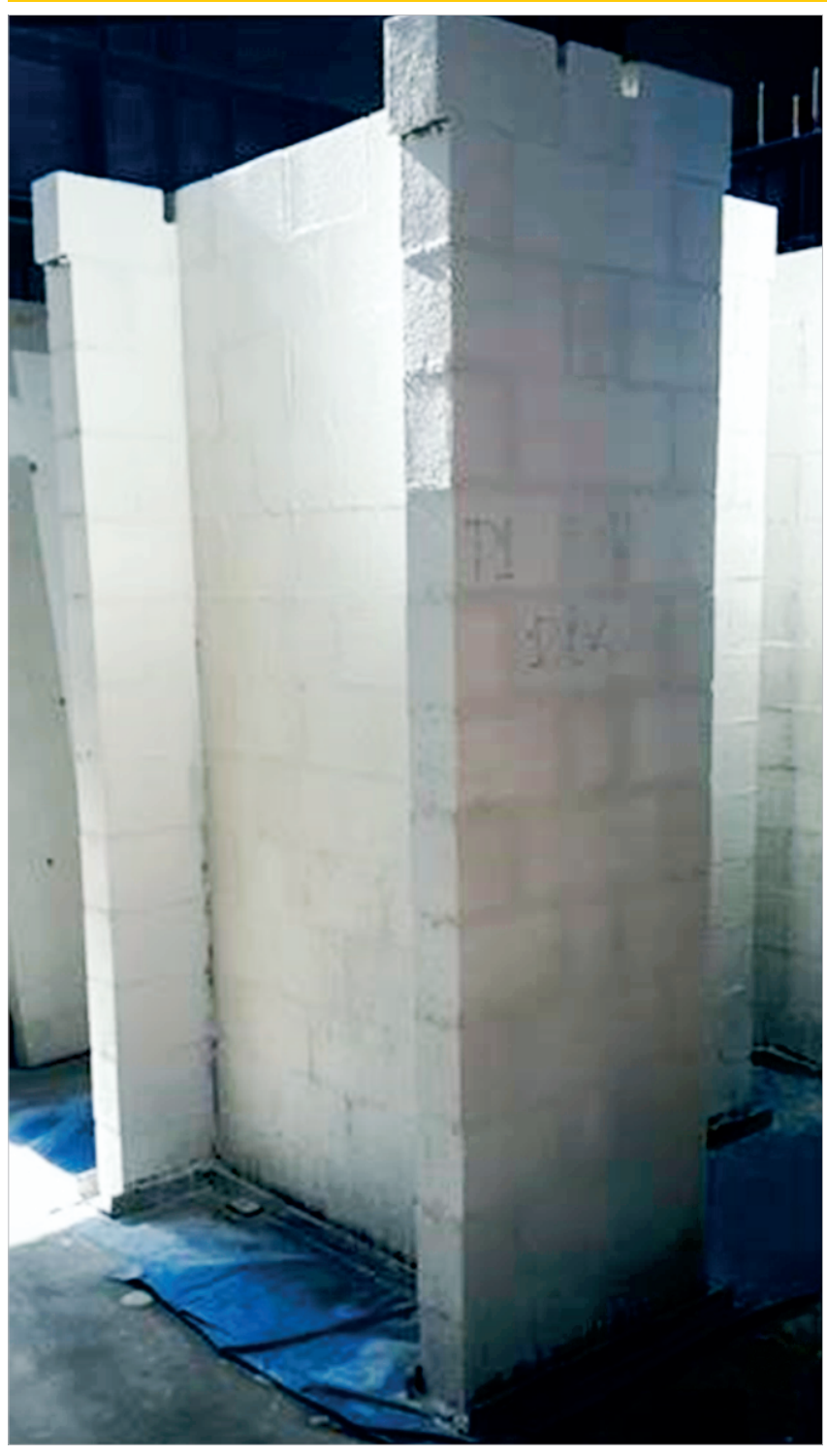

\subsection{Instrumentation and testing procedure}

The procedures for the flanged wall testing complied with the rules from the norm ABNT NBR 8949:1985 [8] that were valid at the date of the testing. The deformations were determined below the top row, to avoid local disturbance in the load application area.

The instrumentation of the flanged walls consisted of a load cell and eighteen displacement transducers, both on the central wall and on the flanges. Figure [4] shows the elevations of the flanged walls (in centimeters) and the position of the sensors on the central wall, the internal and external flanges, respectively. The standard length used for the calculation of vertical deformation was 40 centimeters, which is equivalent to the length of two rows. The labelling of the displacement transducers is shown in Figure [5]. The data

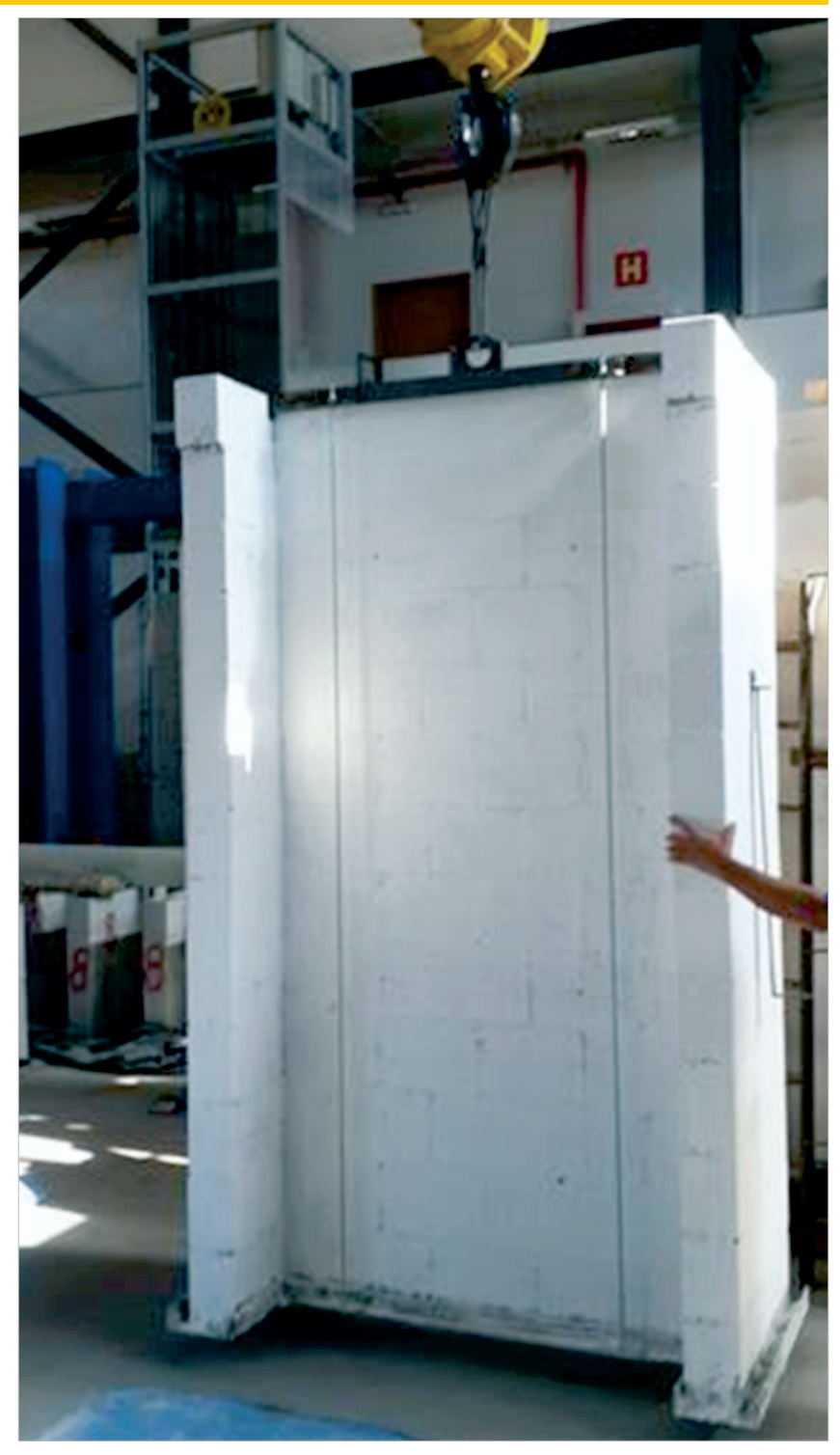

acquisition system Spider was used with a reading frequency of $2 \mathrm{~Hz}$

The loading was divided in four stages and the adopted load increment was $150 \mathrm{kN}$, which is equivalent to around $10 \%$ of the expected failure load. On the first stage, three load increments were applied and subsequently it was unloaded until zero. On the second stage, three load increments were applied and subsequently it was unloaded until $150 \mathrm{kN}$. On the third stage, subsequent increments were applied until the appearance of small fractures. On the fourth and last stage the equipment were removed and the load increment became $50 \mathrm{kN}$, until the rupture of the flanged wall.

After each increment, the load stayed on the flanged walls for a time greater than 5 minutes. The loads and the shortening were registered at the end of this time. Figure [6] shows the 
Figure 4 - Instrumented spots and positions. (a) Central wall - (b) Internal and external flanges Heights in $\mathrm{cm}$
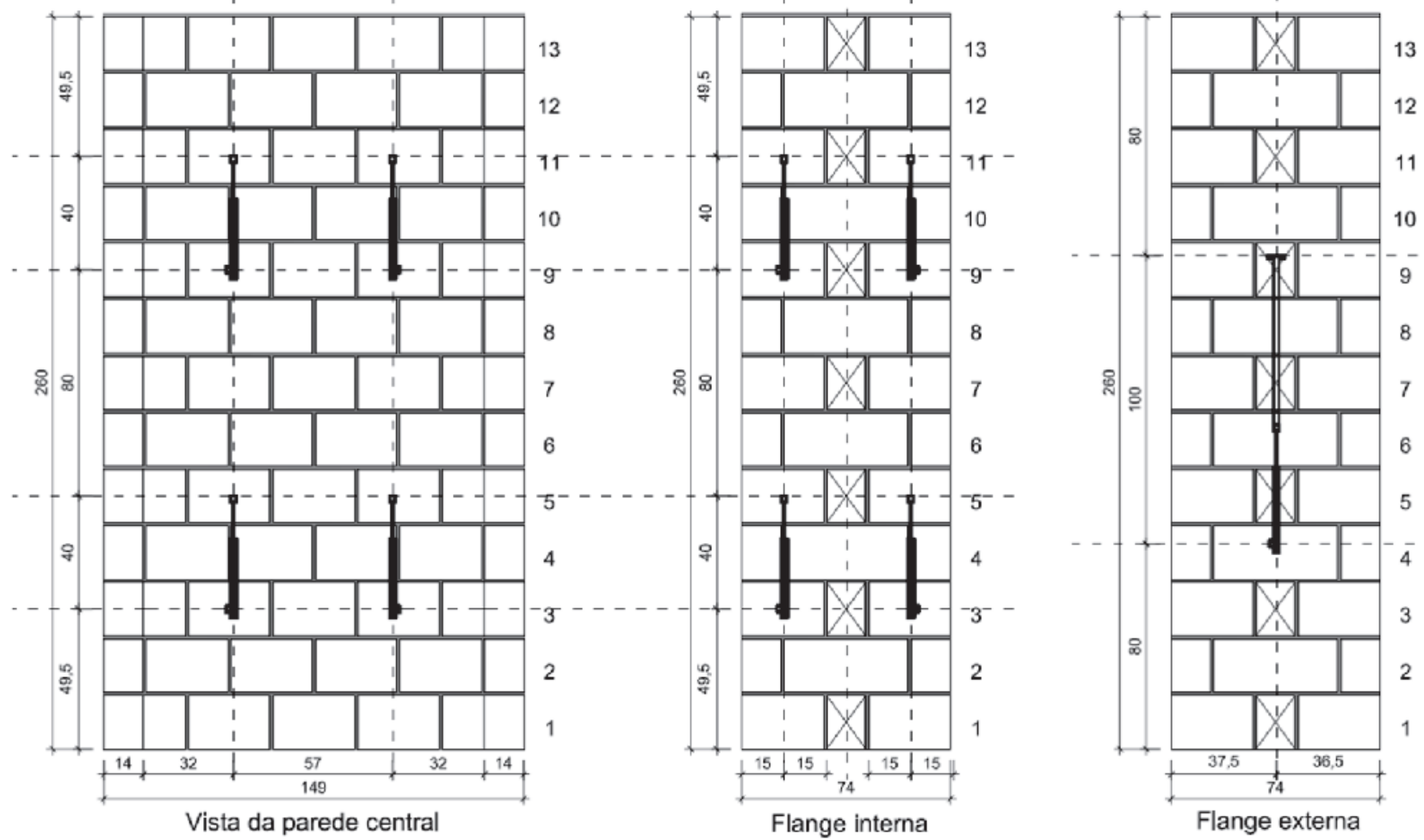

Figure 5 - Labeling of displacement transducers | Upper region (odd numbers) and lower region (even numbers)

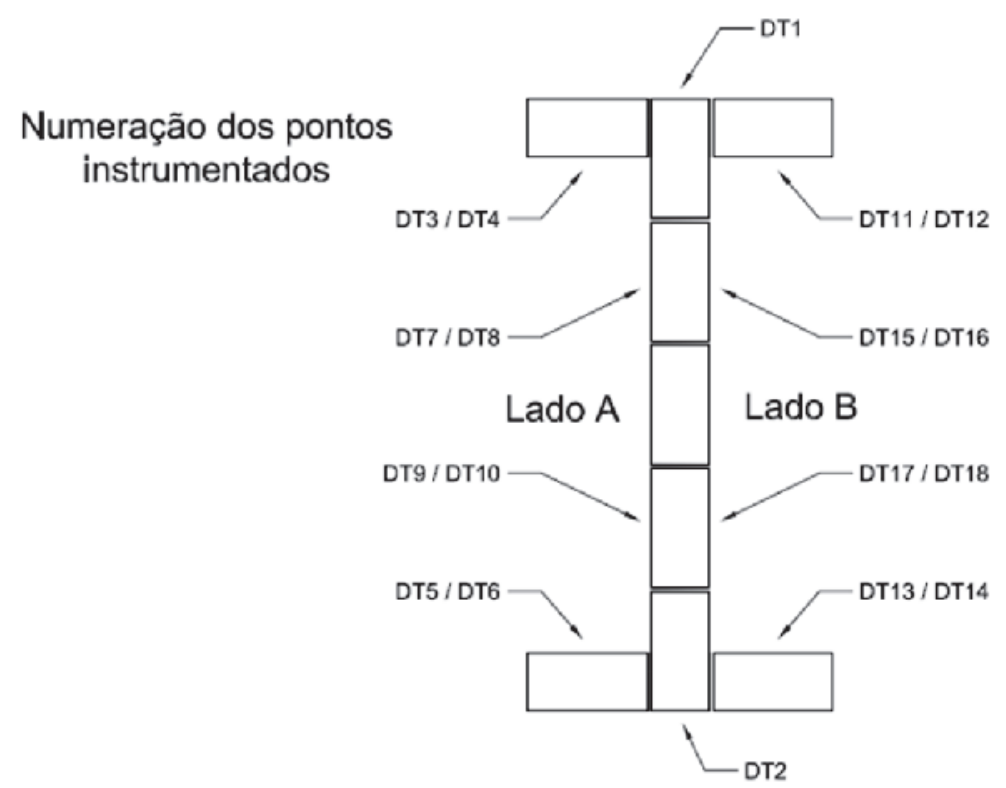

Parte superior: DT3 / DT5 / DT7 / DT9 / DT11 / DT 13 / DT 15 / DT 17

Parte Inferlor: DT4 / DT6 / DT8 / DT10 / DT12 / DT 14 / DT16 / DT 18 


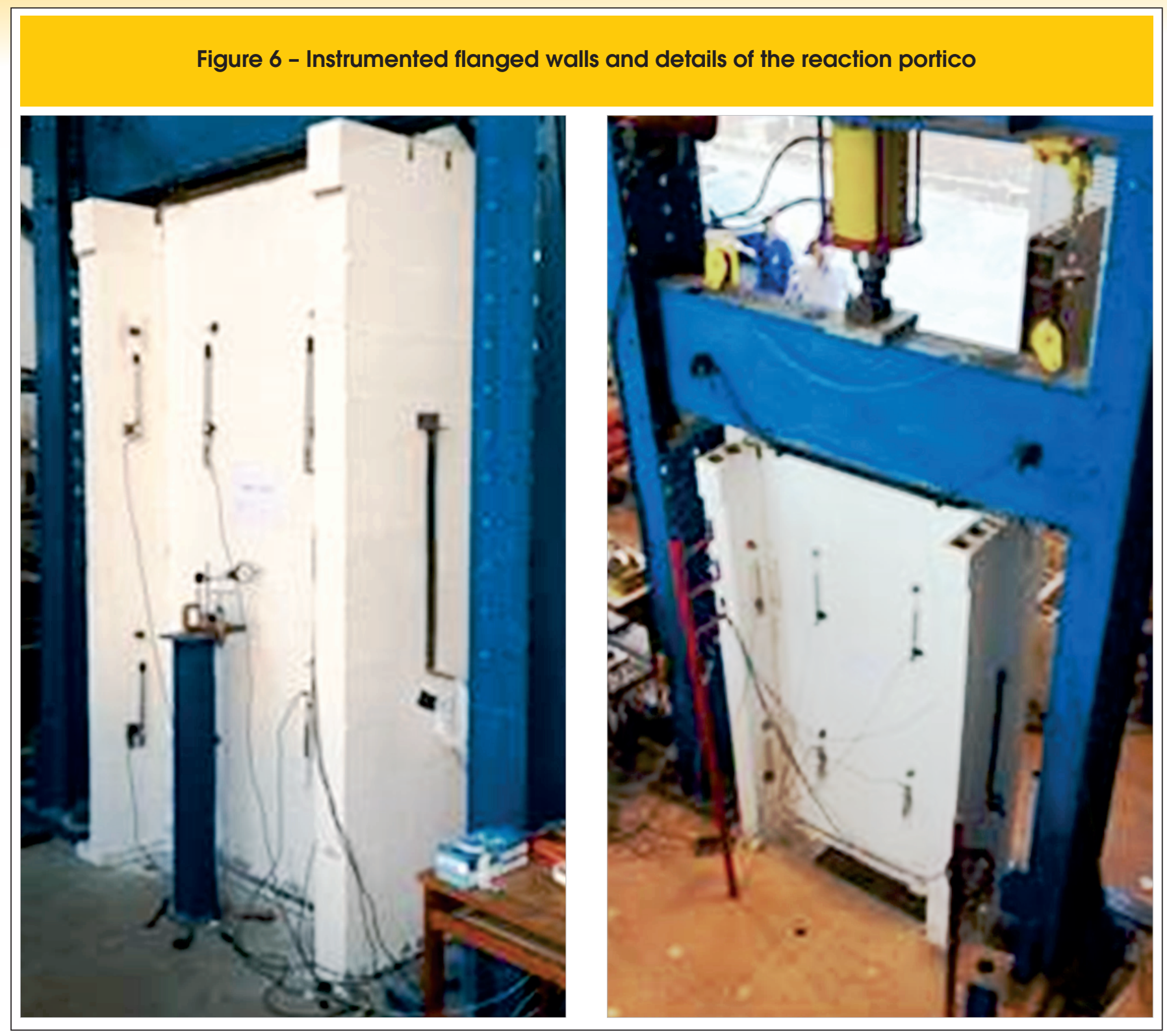

instrumented flanged walls at the moment it was being tested as well as the details of the reaction structures used for the testing. Two kneecaps were used in order to minimize the eccentricity of the load, the first one located at the hydraulic jack and the second one above the steel plate that was supported on the central wall. To improve the support between the metallic framing and the reaction slab and avoid the load to concentrate in local spots, a high initial strength mortar was applied under the framing of every test, according to the arrangement pictured in Figure [7].

\section{$4 \quad$ Material proprieties}

A series of characterization tests were carried out in the masonry components, concrete blocks, mortar and two block prisms, in parallel with the flanged wall testing.

\subsection{Concrete blocks}

The blocks characterization was in terms of the average strength and specific strength, in accordance with the procedures from the ABNT NBR 12118:2014 [13] norm in six specimen. The elasticity modulus and the Poisson ratio were obtained from four elec- tric strain gauge connected to the data acquisition system called AqDados from Lynx. Hence, the blocks were submitted to a load equivalent to $30 \%$ of the failure load and unloaded to achieve stationary state. Then, the loading was applied at a $0,005 \mathrm{~mm} / \mathrm{s}$ rate until reaching $50 \%$ of the possible failure load and finally it was loaded until its rupture.

From the linear interval (stress $x$ strain) the elasticity modulus and the Poisson ratio were obtained, admitting as the linear interval values from $0.5 \mathrm{MPa}$ to $30 \%$ of the average failure load of the blocks. The choice of the testing procedure was based on previous studies found in literature due to the lack of specific norms. Figure [8] illustrates the block instrumentation and the position of the strain gauge on the block.

\subsection{Mortar}

The mortar used to build the prisms and walls in this study contained the following materials as binders: type CP II-E-32 Portland cement, type $\mathrm{CH}$ I special additivated hydrated lime and natural quartzite fine aggregate, upper usable limit.

The method proposed by Santos (2014) [14] was used for the dosage in order to obtain a mortar with compressive strength around $70 \%$ of 
Figure 7 - Instrumented flanged walls and details of the reaction portico

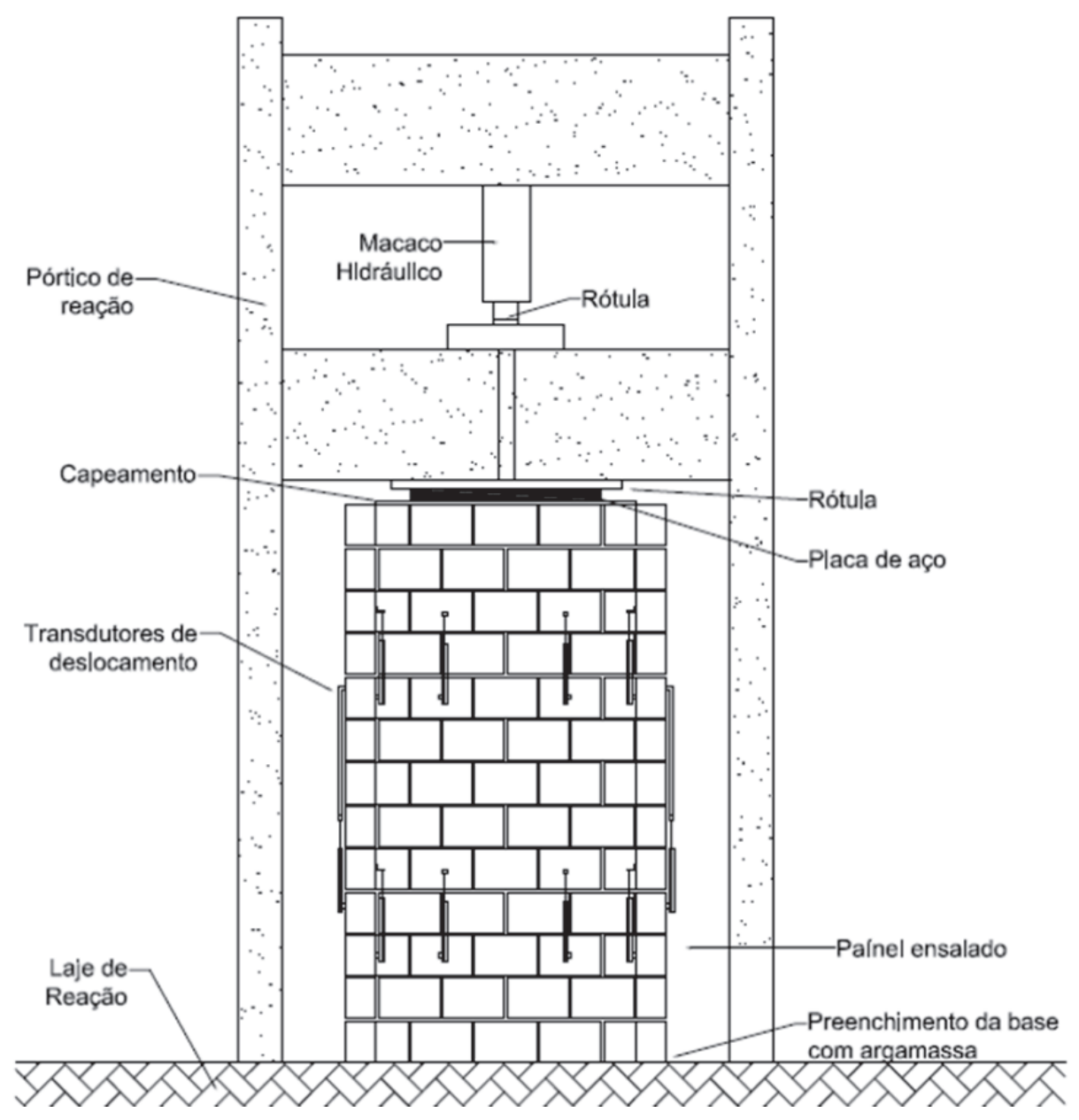

Figure 8 - Instrumented block and details of the strain gauge position
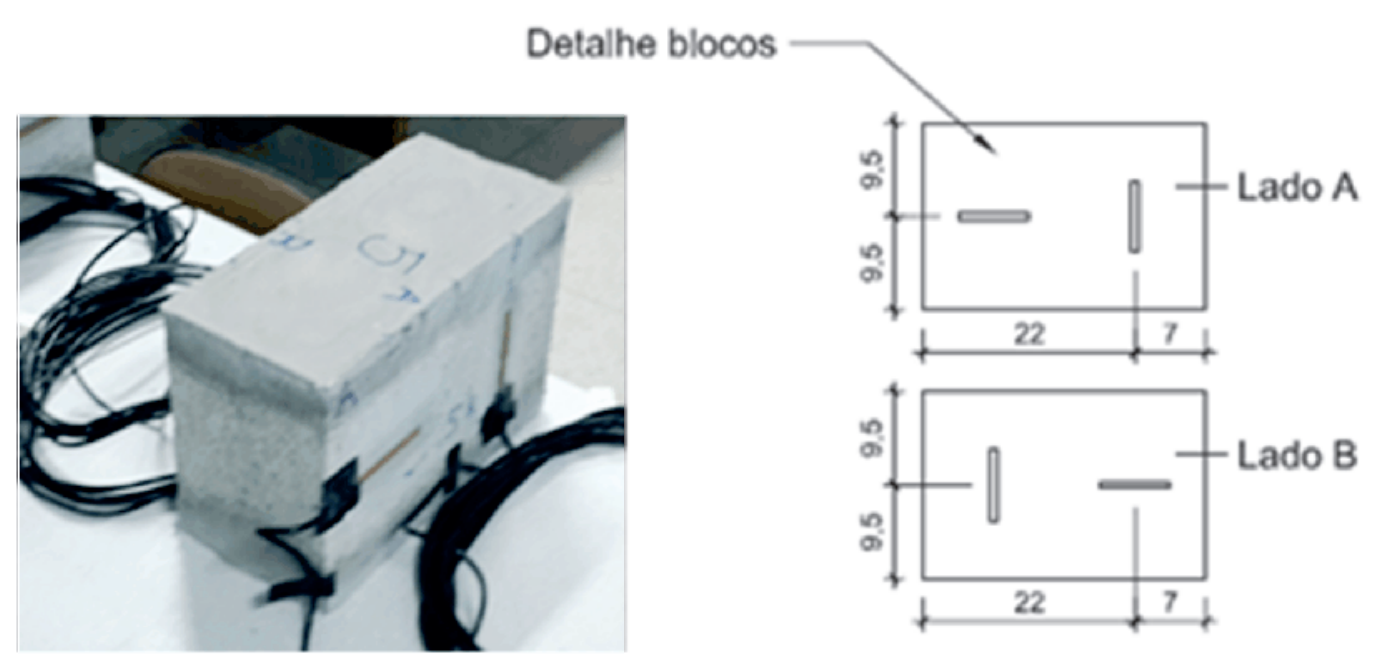


\section{Figure 9 - Testing of prismatic mortar specimen by simple flexion and by compression}

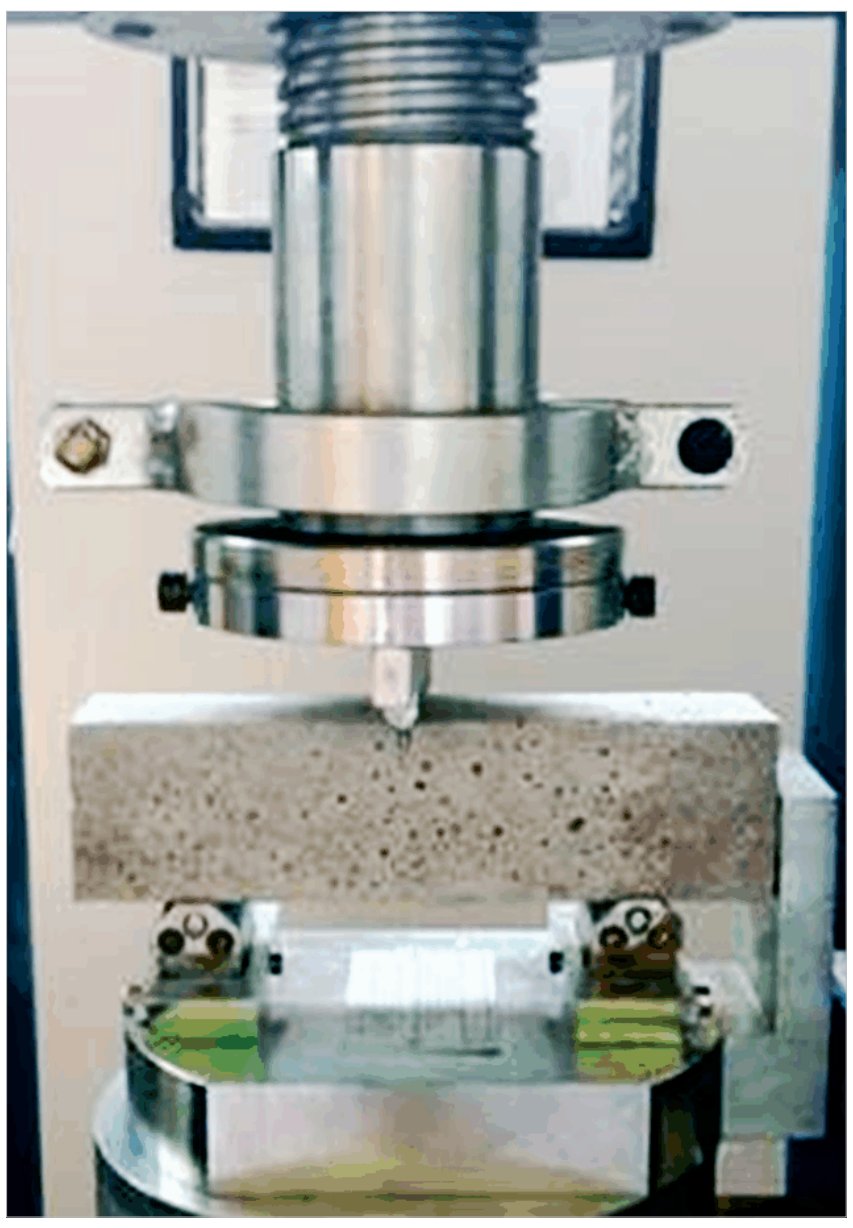

the specific compressive strength of the block (16,9 MPa), in relation to the liquid area. The testing complied with the ABNT NBR 13279:2005 [15] and ABNT NBR 15961-2:2011 [7] norms and were carried on the same day of the walls testing. Figure [9] illustrates the tests for flexural strength and compressive strength. Six mortar specimens $(5 \mathrm{~cm} \times 10$ $\mathrm{cm}$ ) were also built in order to obtain the static and dynamic elasticity moduli. In this case, the norms ABNT NBR 8522:1984 [16] and ABNT NBR 15630:2009 [17] were used, respectively.

\subsection{Two block prisms}

The determination of the prisms compressive strength was carried using the procedures from the ABNT NBR 15961-2:2011 [7] norm. The data acquisition system AqDados from Lynx, with reading frequency of $2 \mathrm{~Hz}$, was used to measure the elasticity modulus. The system collected data from a load cell, four electric strain gauges and two displacement transducers as illustrated in Figure [10].

The prisms were submitted to the testing with manual load application in a portico. Figure [11] illustrates the arrangement set for the experiment. The elasticity modulus of the prisms and the Poisson ratio of the blocks were calculated in the interval of the secant curve correspondent to $5 \%$ to $30 \%$ of each specimen failure load, according to the norm criteria.

\section{Results and discussion}

The experimental results are presented in this topic as well as an

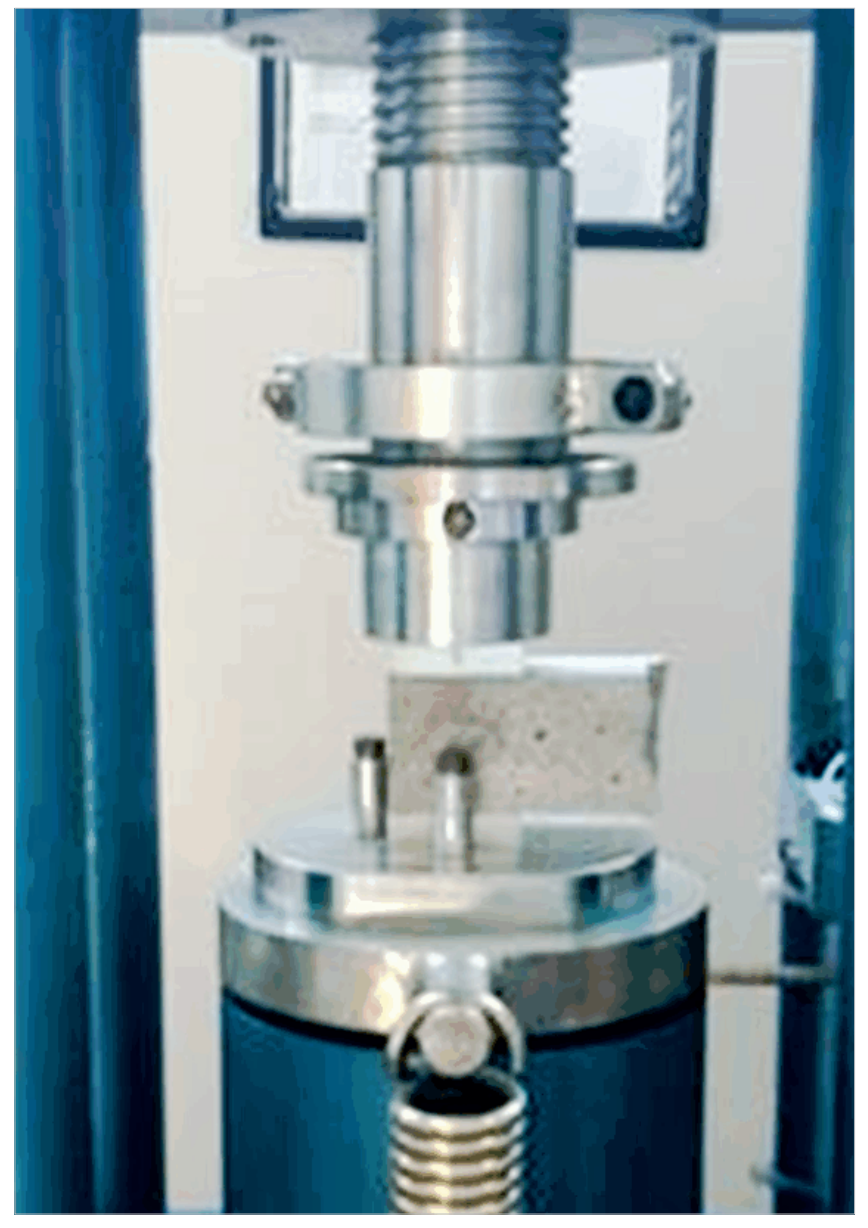

interpretation of the results and comparison with those found by other researchers.

\subsection{Material proprieties}

The average value found in the compression strength test of the concrete block was $20.3 \mathrm{MPa}$ and the specific strength was 16.9 MPa. Both results are shown in details in Table [1]. The average value found in the elasticity modulus test of the block was 20350 $\mathrm{MPa}$. This value is similar to the one calculated with the formula proposed by the $\mathrm{ACl}$ - Building Code 318 [11] (26429 MPa), with a difference of $23 \%$ in the result.

The prisms and the walls were built with the same mortar. The static and dynamic elasticity modulus of the mortar were 9293 $\mathrm{MPa}$ and $7938 \mathrm{MPa}$, respectively. The results differ from each other in $14 \%$ but they did not show disparity in the individual tests, as the coefficient of variation was lower than $5 \%$. Its average compression strength was $11.31 \mathrm{MPa}$ and the flexural strength was $2.70 \mathrm{MPa}$.

The prisms testing aimed to analyze the strength characteristics of the masonry elements, especially the loads and modes of failures, to analyze the axial deformability of the two block prisms and to compare the results to those obtained for walls.

The failure occurred, in general, due to vertical fissure, initiated and intensified in the vertical hollow and in the block longitudinal walls. The first fissures appeared within 70 to $80 \%$ of the maximum load. 
The average value for the elasticity modulus of the prisms was $10008 \mathrm{MPa}$, in other words, there was a reduction of $49.50 \%$ in the elasticity modulus when compared to that of the blocks. The Poisson ratio of the prisms was in average $0.17,22 \%$ lower than the value found for the blocks. This is because the elasticity modulus regards the set block/mortar, being superior to those obtained only by the deformation of the block itself.

Observing the average elasticity modulus of the blocks and mortar, $20350 \mathrm{MPa}$ and $9293 \mathrm{MPa}$, respectively, it results in a ratio of
$\mathrm{E}_{\text {mor }} / \mathrm{E}_{\mathrm{b}}=0,46$. According to Chemma and Klinger (1986) [18], for a ratio of $E_{\text {mor }} / E_{b} \geq 0,6$, the rupture occurs, preferably, by crushing of the mortar joint; while for ratios of $E_{\text {mor }} / E_{b} \leq 0,6$ the rupture occurs by stress on the blocks. In fact, during the tests vertical fissures were observed in the transversal and longitudinal blocks of the prisms.

Table [1] shows a summary of the results presented in this topic.

\section{Figure 10 - Prism ready to be tested and instrumentation scheme}
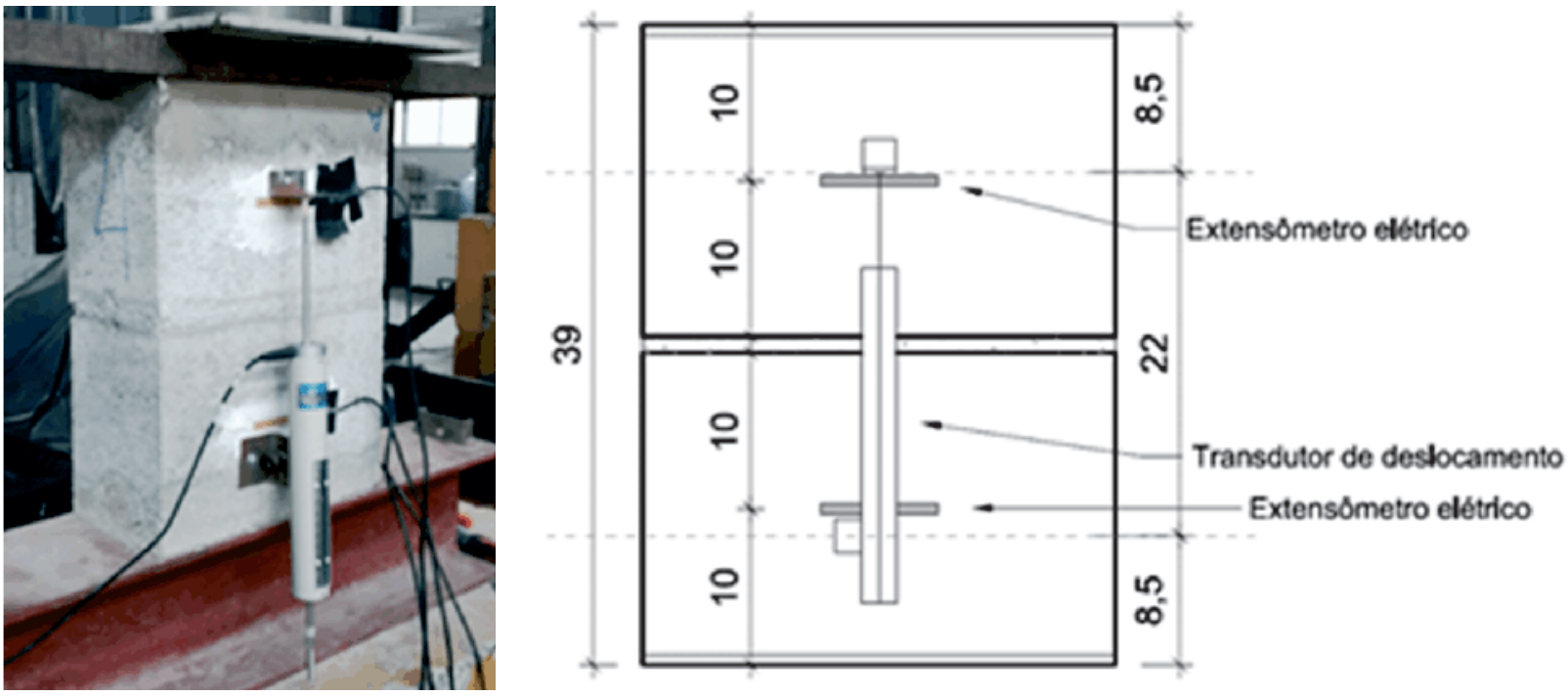

Figure 11 - Prisms testing

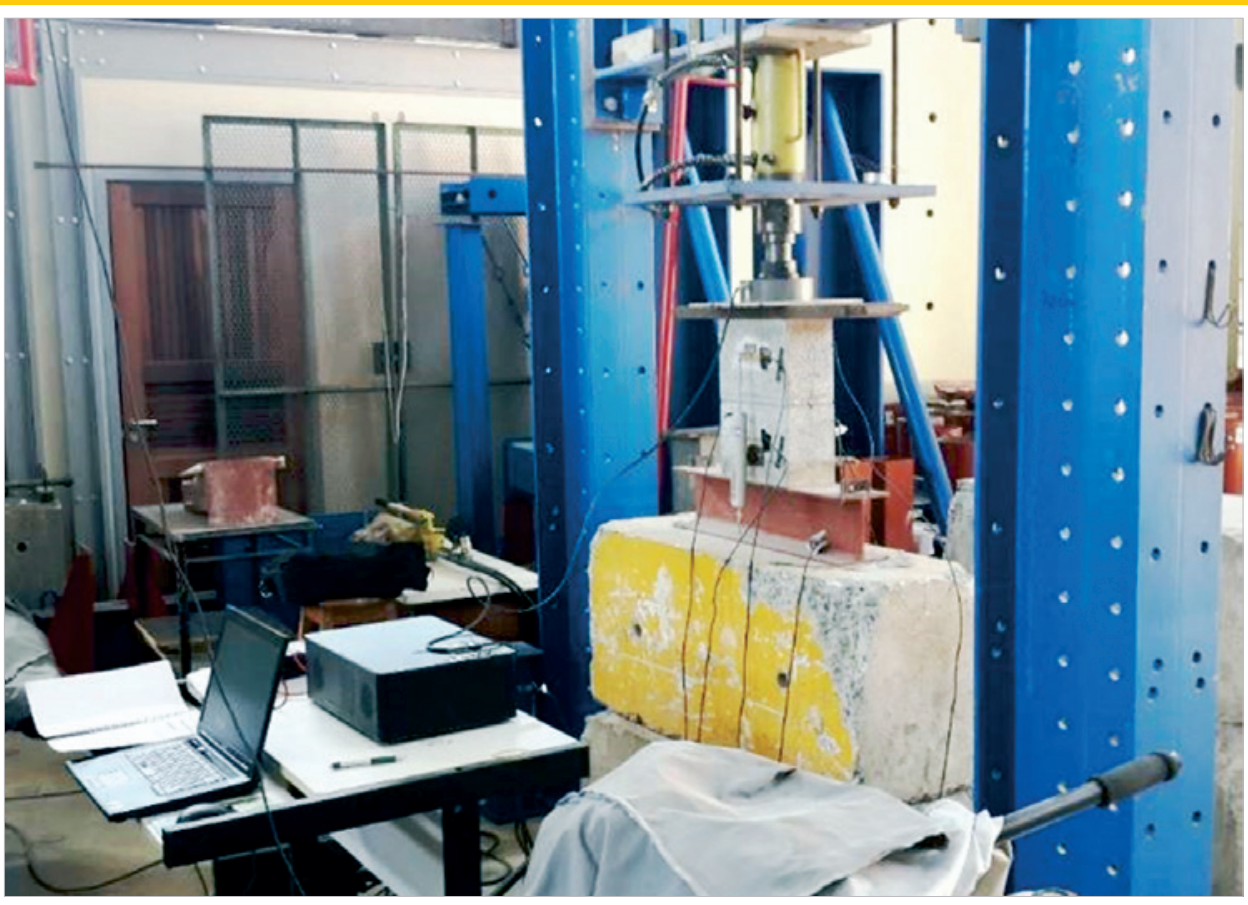


Table 1 - Physical and mechanical proprieties of the materials obtained in the tests

\begin{tabular}{|c|c|c|c|c|}
\hline \multicolumn{2}{|c|}{ Test } & Result & S.D. (MPa) & C.V. (\%) \\
\hline \multirow{9}{*}{ Block (14x29x19) } & Width (mm) & 138,8 & 0,05 & 0,04 \\
\hline & Length (mm) & 289,3 & 0,59 & 0,21 \\
\hline & Height (mm) & 190,1 & 0,25 & 0,13 \\
\hline & $A_{\text {liq }} / A_{\text {gross }}$ & 0,574 & - & - \\
\hline & $w_{b}\left(k g / m^{3}\right)$ & 2187,91 & - & - \\
\hline & $f_{b}(M P a)$ & 20,30 & 2,03 & 10,04 \\
\hline & $f_{b k}(M P a)$ & 16,90 & 2,03 & 10,04 \\
\hline & $\mathrm{E}_{\mathrm{b}}(\mathrm{MPa})$ & 20350 & 2254,73 & 11,08 \\
\hline & v & 0,22 & 0,08 & 38,41 \\
\hline \multirow{3}{*}{ Mortar } & $\mathrm{F}_{\mathrm{mc}}(\mathrm{MPa})$ & 11,31 & 0,33 & 2,93 \\
\hline & $\mathrm{F}_{\mathrm{mt}}(\mathrm{MPa})$ & 2,70 & 0,13 & 4,71 \\
\hline & $\mathrm{E}_{\mathrm{m}}$ static (MPa) & 9293 & 412,00 & 4,43 \\
\hline \multirow{6}{*}{ Prisms } & $f_{p}(M P a)$ & 13,7 & 2,47 & 17,97 \\
\hline & $f_{p k}(M P a)$ & 11,7 & 2,47 & 17,97 \\
\hline & $f_{p} / f_{b}(\%)$ & 57,50 & - & - \\
\hline & $f_{p k} / f_{b k}(\%)$ & 69,06 & - & - \\
\hline & $E_{p}$ & 10008 & 434,83 & 4,34 \\
\hline & u & 0,17 & 0,02 & 8,96 \\
\hline
\end{tabular}

\subsection{Masonry flanged walls}

For a better understanding, the results were divided in five subtopics: Compressive strength, deformation, modes of failure, estimation of transfer rates and comparative analysis between walls with and without central support.

\subsubsection{Compressive strength}

The load correspondent to the appearance of the first visible fissures in each test and that of the failure are presented in Table [2]. Table [3] shows the failure loads considering independent walls and walls with interaction. The compressive strength of the prismatic mor- tar specimens, which were retained during the construction of the flanged walls, had similar results to what was expected (12.0 MPa), only a little over due to a longer curing time of the mortar.

\subsubsection{Deformation}

Only the deformation measured in the lower part of the wall was used to calculate the elasticity modulus of the flanged walls. In the upper region, where the load transfer from the central wall to the flanges occur, the determination of the stress acting on the web / flange is complex and uncertain. The load interval used to calculate the stress was between $30 \%$ and $40 \%$ of the failure load, as linear scopes are observed in this interval and the load values are lower than the first fissure load.

\section{Table 2 - First fissure load and maximum load}

\begin{tabular}{|cccc|}
\hline Wall type & Test & First fissure load (kN) & Maximum load (kN) \\
\hline \multirow{2}{*}{ With central support } & 1 & 642,48 & 879,46 \\
& 2 & 728,25 & 1294,60 \\
& 3 & 703,00 & 952,73 \\
& Average (kN) & 697,24 & 1042,26 \\
Without central support & S.D. (kN) & 44,08 & 221,58 \\
& C.V. (\%) & 6,38 & 21,26 \\
& 4 & 545,82 & 704,61 \\
& 5 & 478,16 & 593,77 \\
& 6 & 621,10 & 673,24 \\
& Average & 581,69 & 657,20 \\
\hline
\end{tabular}


Table 3 - Failure load

\begin{tabular}{ccccccc}
\hline Type & \multicolumn{2}{c}{ Stress in independent wall (MPa) } & \multicolumn{3}{c|}{ Stress in walls with interaction(MPa) } \\
\hline & Average (MPa) & S.D. (MPa) & C.V. (\%) & Average (MPa) & D.P. (MPa) & C.V. (\%) \\
$\begin{array}{c}\text { With central } \\
\text { support }\end{array}$ & 6,15 & 1,31 & 21,26 & 2,75 & 0,58 & 21,26 \\
$\begin{array}{c}\text { Without central } \\
\text { support }\end{array}$ & 3,17 & 0,27 & 8,72 & - & - \\
\hline
\end{tabular}

Table 4 - Elasticity modulus (wall with central support)

\begin{tabular}{|c|c|c|c|c|c|c|c|}
\hline Flanged wall & \multicolumn{2}{|c|}{ Load (kN) } & $\begin{array}{l}\text { Stress on the } \\
\text { web (MPa) }\end{array}$ & Def. 1 & Def. 2 & $\begin{array}{l}\text { Elasticity } \\
\text { modulus } 1\end{array}$ & $\begin{array}{l}\text { Elasticity } \\
\text { modulus } 2\end{array}$ \\
\hline \multirow{2}{*}{1} & $30 \%$ & 26,38 & 1,20 & 0,0004351 & 0,0011511 & 7740 & 3306 \\
\hline & $40 \%$ & 35,17 & 2,04 & 0,0003273 & 0,0008988 & 7740 & 3306 \\
\hline \multirow{2}{*}{2} & $30 \%$ & 38,84 & 1,25 & 0,0006610 & 0,0013659 & 7756 & 3016 \\
\hline & $40 \%$ & 51,78 & 2,95 & 0,0004406 & 0,0007993 & 7756 & 3016 \\
\hline \multirow{2}{*}{3} & $30 \%$ & 28,58 & 0,81 & 0,0004683 & 0,0009824 & 3870 & 5729 \\
\hline & $40 \%$ & 38,11 & 1,58 & 0,0002691 & 0,0008478 & 3870 & 5729 \\
\hline $\begin{array}{l}\text { Average } \\
\text { (MPa) }\end{array}$ & & & & & & \multicolumn{2}{|c|}{5236} \\
\hline S.D. (MPa) & & & & & & \multicolumn{2}{|c|}{384,6} \\
\hline C.V. (\%) & & & & & & \multicolumn{2}{|c|}{7,35} \\
\hline
\end{tabular}

\section{Table 5 - Elasticity modulus (wall without central support)}

\begin{tabular}{|c|c|c|c|c|c|c|}
\hline Flanged wall & & & Transfer rate & $\begin{array}{l}\text { Stress on the } \\
\text { flange (MPa) }\end{array}$ & Def. & $\begin{array}{l}\text { Elasticity } \\
\text { modulus }\end{array}$ \\
\hline \multirow{2}{*}{1} & $30 \%$ & 10,57 & $100 \%$ & 1,34 & 0,0003411 & 5897 \\
\hline & $40 \%$ & 14.09 & $100 \%$ & 1,01 & 0,0002842 & 5897 \\
\hline \multirow{2}{*}{2} & $30 \%$ & 89,07 & $100 \%$ & 1,13 & 0,0000801 & 3529 \\
\hline & $40 \%$ & 11,88 & $100 \%$ & 0,85 & 0,0000000 & 3529 \\
\hline \multirow{2}{*}{3} & $30 \%$ & 10,10 & $100 \%$ & 1,28 & 0,0000272 & 7209 \\
\hline & $40 \%$ & 13,47 & $100 \%$ & 0,96 & 0,0000227 & 7209 \\
\hline Average (MPa) & & & & & & 5545 \\
\hline S.D. (MPa) & & & & & & 1868,1 \\
\hline C.V. (\%) & & & & & & 33,64 \\
\hline
\end{tabular}

In order to determine the loads and stresses of the flanged walls with central support, the ratio between the deformations of the displacement transducers placed on the web and on the flanges was calculated. All of them were placed on the same height; therefore the rate of load transfer from the web to the flanges was estimated. For the flanged walls without central support, on the other hand, the elasticity modulus was calculated using the deformation in the lower part of the flanges. The stress was obtained considering half the load of each flange, being the load transfer from the web to the flanges of $100 \%$ giving the condition of no support of the central wall. It was possible to observe that in the lower region of the flanged wall, the readings of the displacement transducer on the web and the flanges were closer, indicating the occurrence of interaction. The deformation of the flanges in the lower region were superior to those measured in the upper region. Meanwhile, on the web there was a reduction on the deformation in the lower region when compared to the upper one. The results are shown in Table [4] and Table [5].

\subsubsection{Modes of failure}

The modes of failure can be observed on Figure [12] to Figure [17]. On the flanged walls with central support, the modes of failure 

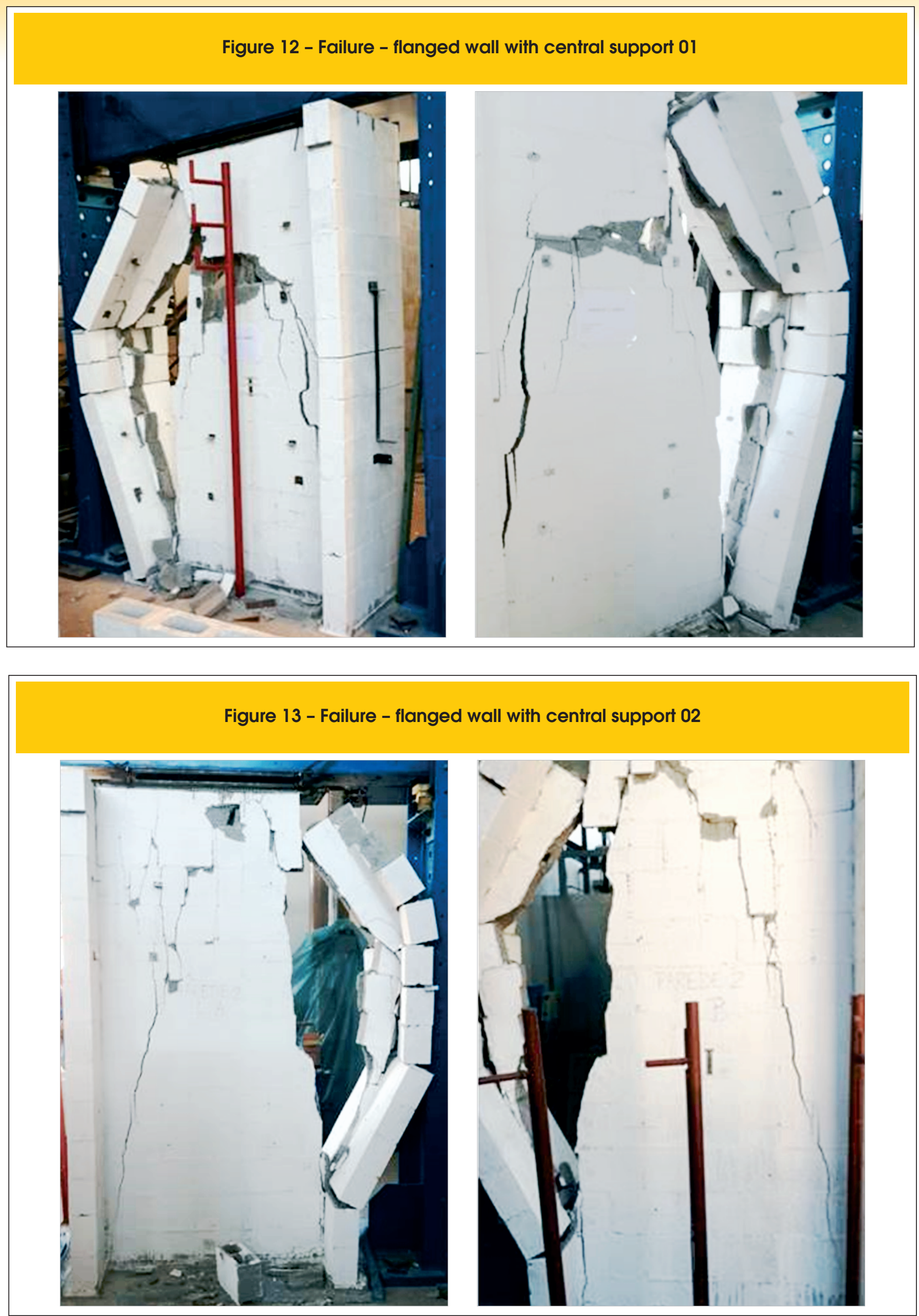
Figure 14 - Failure - flanged wall with central support 03
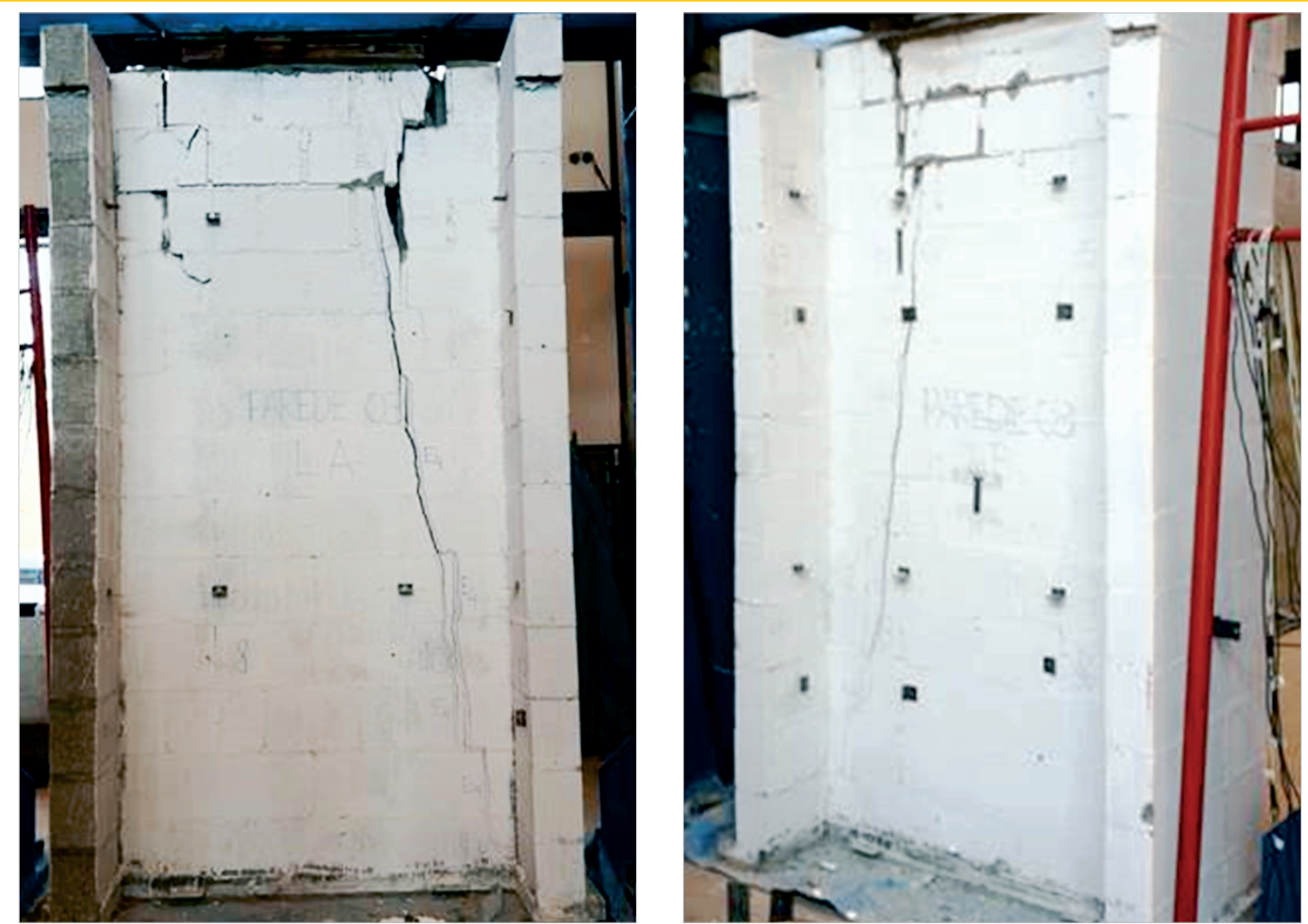

Figure 15 - Failure - flanged wall without central support 04
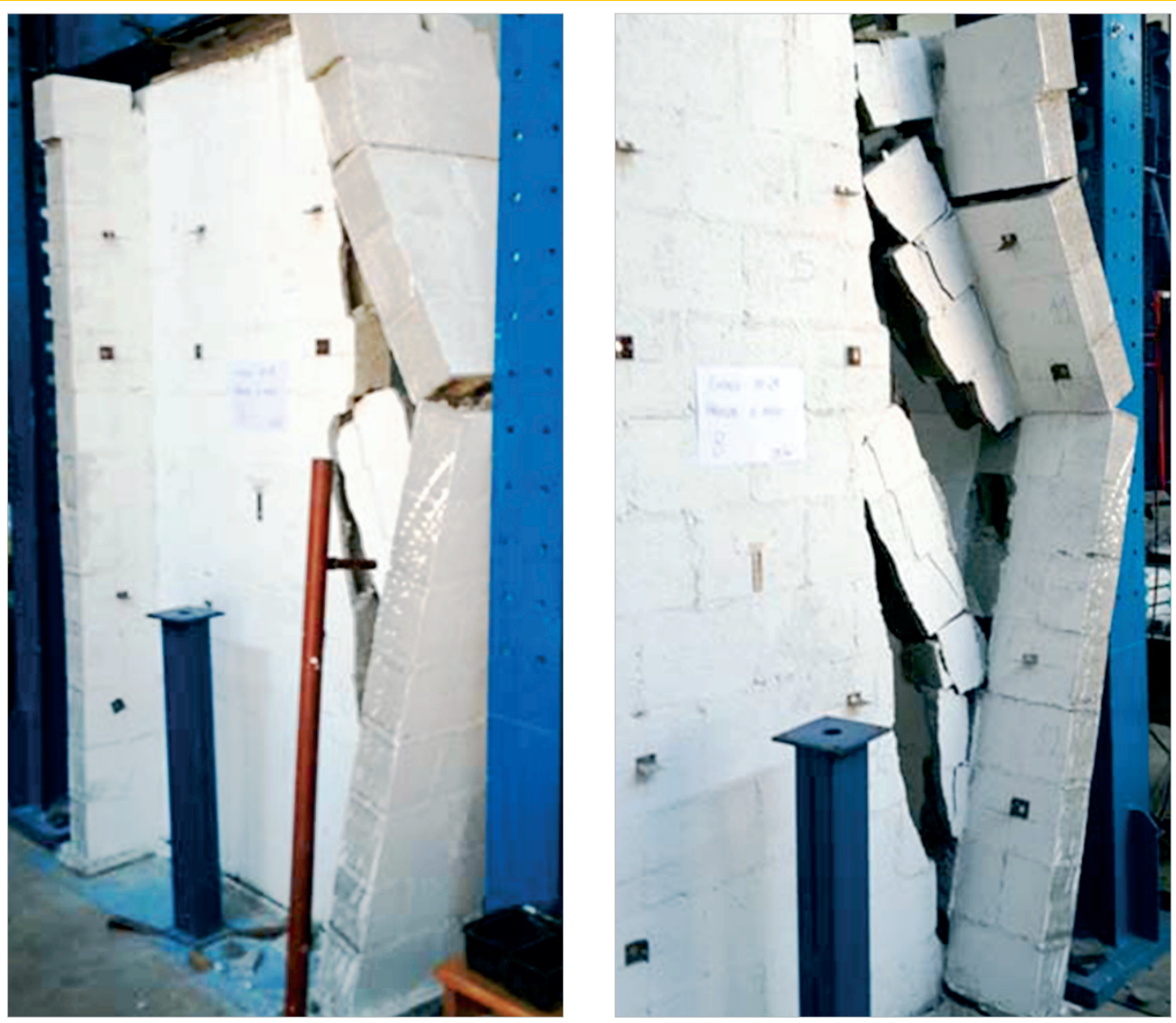
Figure 16 - Failure - flanged wall without central support 05
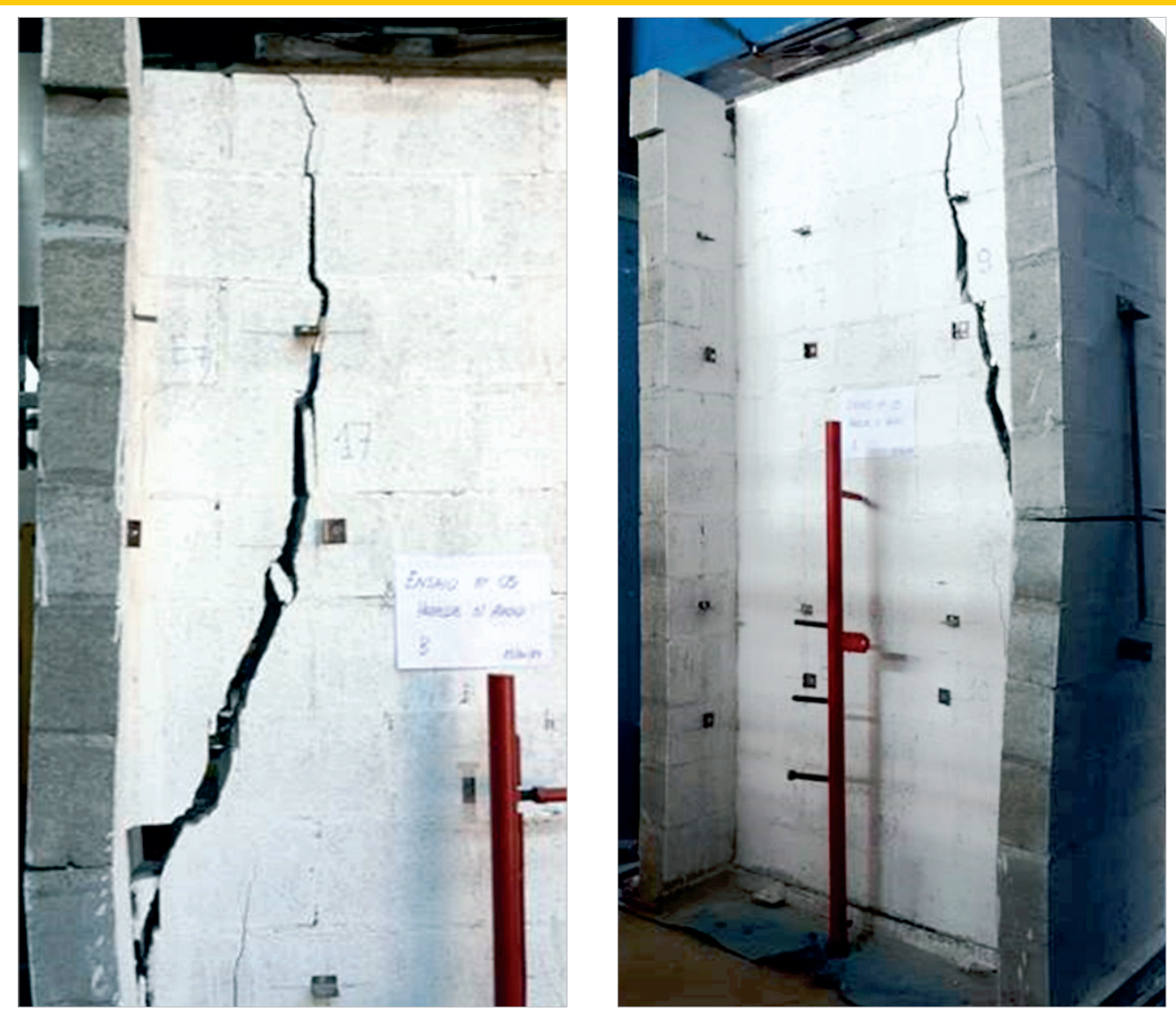

Figure 17 - Failure - flanged wall without central support 06
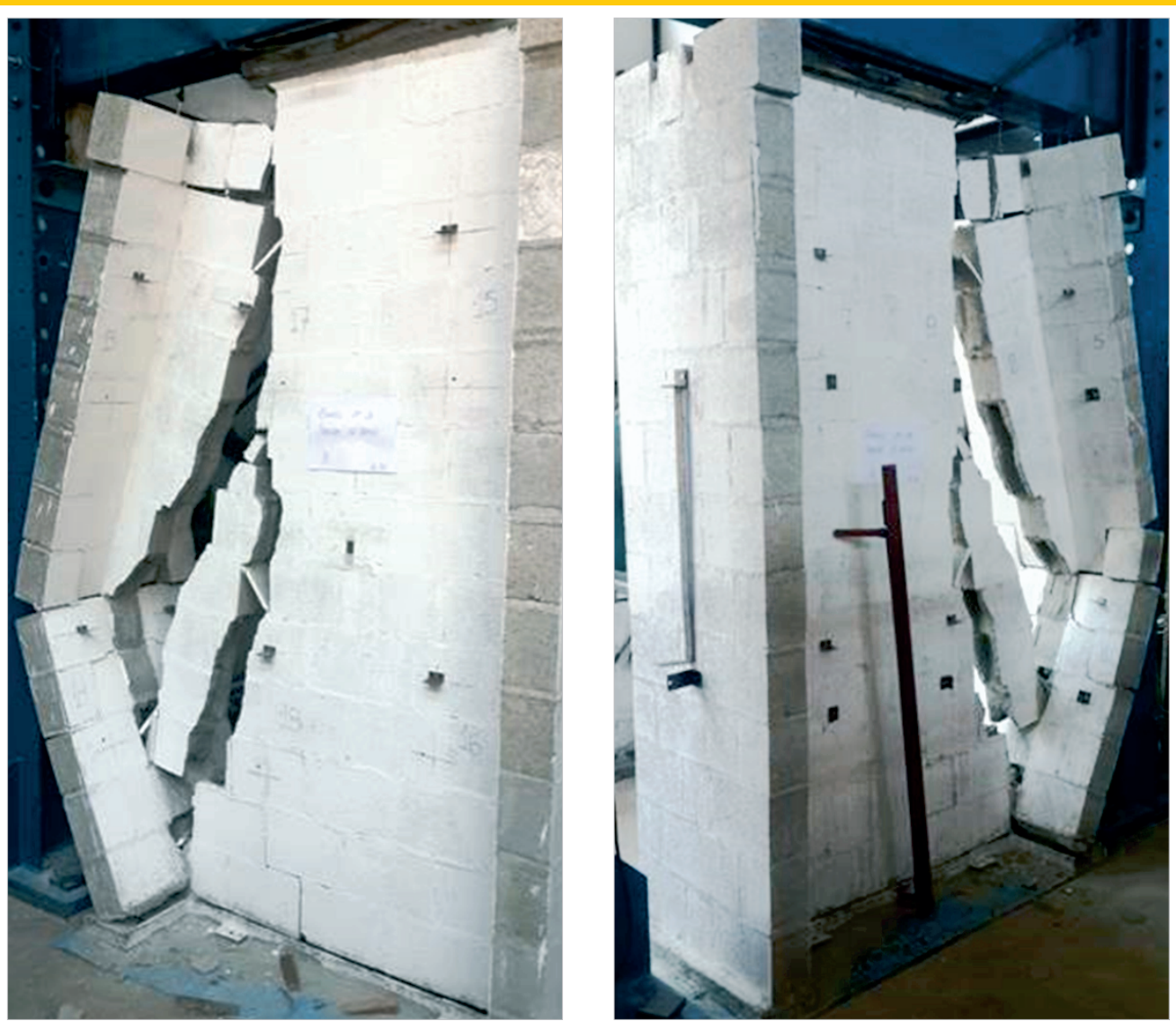


\section{Table 6 - Average deformation ratio on the flanges and webs and the load transfer rate for the flanges}

\begin{tabular}{|c|c|c|c|c|c|c|c|}
\hline \multirow{2}{*}{ Test } & \multicolumn{2}{|c|}{$\begin{array}{c}\text { Average deformation on } \\
\text { flange / Average deformation } \\
\text { on web (r) }\end{array}$} & \multicolumn{2}{|c|}{$\begin{array}{l}\text { Load transferred to flange } \\
\text { (kN) }\end{array}$} & \multirow{2}{*}{$\begin{array}{l}\text { Max. strength } \\
\text { on flange } \\
\text { (kN) }\end{array}$} & \multicolumn{2}{|c|}{$\begin{array}{l}\text { Transfer rate } \\
\text { to flange (\%) }\end{array}$} \\
\hline & $\begin{array}{l}\text { Upper } \\
\text { region }\end{array}$ & Lower region & $\begin{array}{l}\text { Upper } \\
\text { region }\end{array}$ & Lower region & & $\begin{array}{l}\text { Upper } \\
\text { region }\end{array}$ & Lower region \\
\hline Panel 1 & 0,26 & 0,57 & 107,2 & 182,1 & 240,4 & 44,60 & 75,76 \\
\hline Panel 2 & 0,19 & 0,64 & 123,4 & 286,4 & 353,3 & 34,93 & 81,06 \\
\hline Panel 3 & 0,18 & 0,56 & 86,9 & 195,2 & 260,0 & 33,42 & 75,07 \\
\hline Average & 0,21 & 0,59 & 105,8 & 221,2 & 284,5 & 37,65 & 77,30 \\
\hline
\end{tabular}

of the first two walls were similar, typical of a failure by combined compression and shear, with horizontal traction failure along the web and shear in the lower region at the web/flange interface. The fissures started vertically below the load application point (passing through the horizontal joints of the blocks) and staggered (only through the vertical and horizontal mortar joints).

In the third flanged wall with central support, the failure occurred by compression in the upper region of the central wall in the blocks below the first row. By increasing the load, the fissures propagated down.

On the flanged walls without central support, the three tests showed similar behaviors, in which the failure occurred abruptly with the sudden opening of big fissures, typical of shear failure. In all the cases, the failure occurred in only one side with a vertical fissure along the web. The effect of bending on the flanges can be verified by the horizontal cracks occurring at the joints of the intermediate rows.

Generally, from the load application point, the cracking displaced vertically, with a slight inclination, and on the lower rows, they inclined in the direction of the flanges, clearly indicating the shear on the web/flanges interface.

\subsubsection{Transfer rate}

Load transfer rate to the flanges is understood as the relationship between the portion of the load applied on the web that is absorbed by the flanges and the maximum load that can be transferred to the flanges in the case of a complete interaction. For the totally supported " $\mathrm{H}$ " shaped walls, it was observed that the transfer rate is conditioned by the level of load applied on the central wall as much as on the position evaluated on the wall (height).

For the panels with central support, the interaction rate was determined based on the strain relationships and the strength of materials and mechanical equations. Neglecting the flexion effect, it can be said that:

$\therefore F_{\text {flange }}=\frac{1}{(k / r+2)} \times F_{t}$

where:

$k=\left(\frac{A_{\text {web }} \times E_{\text {web }}}{A_{\text {flange }} \times E_{\text {flange }}}\right), E_{\text {web }}=E_{\text {flange }}=E_{\text {masonry }} ; r=\frac{\varepsilon_{\text {flange }}}{\varepsilon_{\text {web }}}$

and $F_{t}$ is the total load applied at the top.
On the other hand, for the total uniformization case:

$$
\sigma_{\text {wall }}^{t}=\frac{F_{t}}{\left(A_{\text {web }}+2 \times A_{\text {flange }}\right)}
$$

for walls with central support

$$
F_{\text {flange }}^{\text {uni }}=\sigma_{\text {wall-1 }}^{t} \times A_{\text {flange }}
$$

for walls without central support

In which:

$\sigma_{\text {wall }}^{t}$ is the uniform stress on the web and the flanges

$F_{\text {flange }}^{\text {uni }}$ is the net force on the flange correspondent to the uni-

The ratio between the average deformations on the flanges and the webs, obtained experimentally for the flanged walls with and without central support, respectively, are shown on Table [6], as well as the interaction rates for the flange on the panels with central support.

Figure [18] and Figure [19] show the relationship between the average deformation on the flange and the average deformation on the wall as a function of the level of load applied on the tests for both series.

\subsubsection{Comparative analysis between flanged walls with and without central support}

It cam be said that for the "H" shaped walls without central support (Average failure load $657 \mathrm{kN}$ ) there was a decrease of $36.9 \%$ in the average failure load when compared to the flanged wall series with central support (Average failure load $1042 \mathrm{kN}$ ). This is due to the reduction in $45 \%$ of the supporting area.

Based on the theoretical procedures for distribution of vertical actions so-called independent walls and walls with interaction, it was concluded that the stresses required by the web and the flanges are around $6.15 \mathrm{MPa}$ and $2.75 \mathrm{MPa}$, respectively, for flanged walls with central support. The stress considering an independent wall was $3.17 \mathrm{MPa}$, for walls without central support.

From the results obtained for the compressive strength of the blocks and for the prism/block efficiency it was possible to estimate the fail- 
ure load of the flanged walls with central support as being 1302.60 $\mathrm{kN}$, using the independent walls method. However, when the stiffness effect and the slenderness ratio $(R)$ are considered or not, the estimated value of the failure load are $1276.55 \mathrm{kN}$ and $1172.34 \mathrm{kN}$, respectively. The difference between the expected values and the average obtained experimentally relates to the fact that masonryflanged walls can fail due to the stress concentration in local spots.

The average elasticity modulus of the flanged walls was $5236 \mathrm{MPa}$

Figure 18 - Average deformation ratio (flange/web) - flanged walls with central support

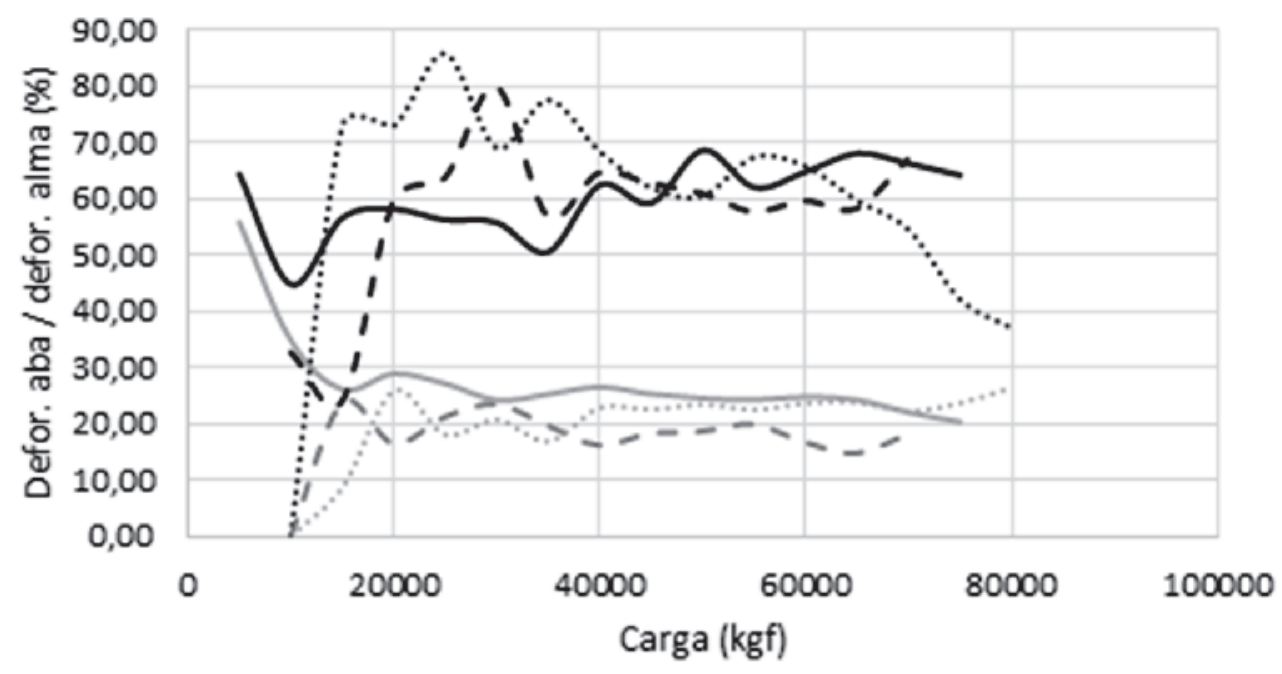

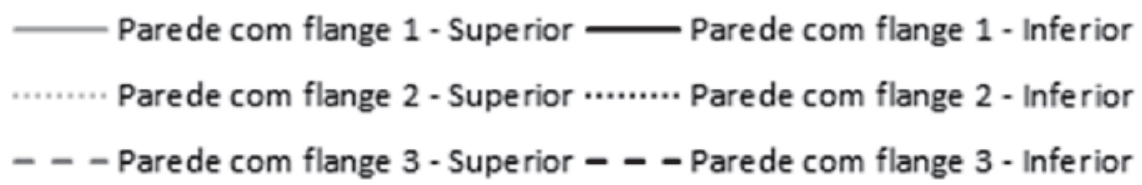

Figure 19 - Average deformation ratio (flange/web) - flanged walls without central support

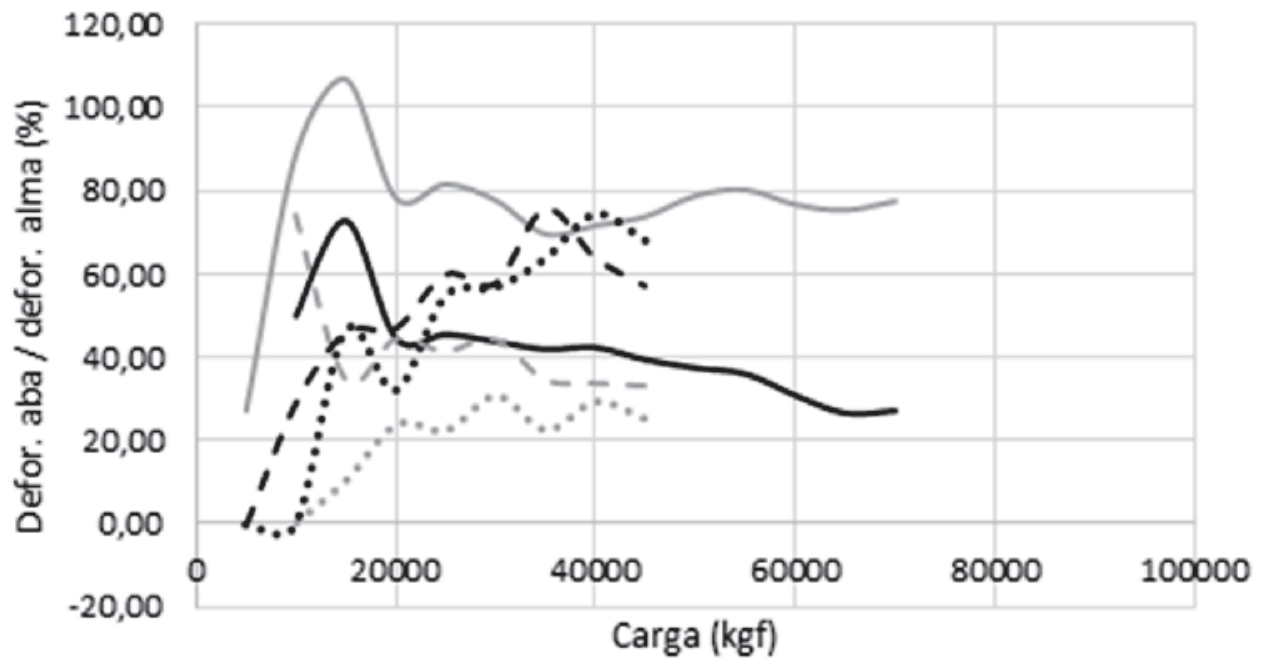

— Parede com flange 4 - Superior ——Parede com flange 4 - Inferior

Parede com flange 5 - Superior ....... Parede com flange 5 - Infe iror

- - - Parede com flange 6 - Superior - - - Parede com flange 6 - Inferior 
Table 7 - Masonry elasticity modulus

\begin{tabular}{|c|c|c|c|c|c|}
\hline \multirow[t]{2}{*}{ Type } & $\begin{array}{l}\text { Experimental } \\
\text { program }\end{array}$ & $\begin{array}{c}\text { ABNT NBR } \\
15961-1: 2011\end{array}$ & Gomes (1993) & $\begin{array}{c}\text { Dhannasekar } \\
(1985)-\end{array}$ & $\begin{array}{l}\text { Dhannasekar } \\
\text { (1985) - walls with } \\
\text { interaction }\end{array}$ \\
\hline & \multicolumn{5}{|c|}{$\mathrm{MPa}$} \\
\hline $\begin{array}{l}\text { With central } \\
\text { support }\end{array}$ & 728,25 & 8960 & 8995 & 5329 & 2732 \\
\hline $\begin{array}{c}\text { Without central } \\
\text { support }\end{array}$ & 703,00 & 8960 & 8995 & 3558 & 1859 \\
\hline
\end{tabular}

(web - wall with central support) and $5545 \mathrm{MPa}$ (flange - wall without central support) and, despite being calculated differently, the values were similar.

The masonry elasticity modulus according to the ABNT NBR 15961-1:2011 [3] norm can be estimated as being $800 \times \mathrm{f}_{\mathrm{pk}}$. For $\mathrm{f}_{\mathrm{pk}}$ equals to $11.7 \mathrm{MPa}$, the expected elasticity modulus would be $9360 \mathrm{MPa}$, which is greater than the one found in this study.

Other authors suggest equations to calculate the elasticity modulus. The Equation (2.4) proposed by Gomes (1993, apud CARVALHO, 2007) [12] allows the calculation of the masonry elasticity modulus as a function of the elasticity modulus of the mortar and the block. Using the Equation (2.4) for the data found in this experiment ( $E_{a}$ being $8616 \mathrm{MPa}$ and $E_{b}$ being $20350 \mathrm{MPa}$ ), the elasticity modulus of the masonry is $8995 \mathrm{MPa}$.

The Equation (2.5) proposed by Dhanasekar (1985, apud MOHAM$A D, 2007)[9]$ suggests a linear relationship to establish the elasticity modulus of the masonry as a function of its compressive strength. Using the theoretical methods for calculating stresses (independent walls and walls with interaction), two values of elasticity modulus were found. Table [7] shows the results of elasticity modulus found in this study as well as those obtained from equations available in literature. It is clear that the model with closer results to those found in this study was from Dhammasekar (1985, apud MOHAMAD, 2007) [9]. The formation of strut on the central wall was evident in the failure mode due to the formation of cracking and fissures with inclination between $60^{\circ}$ and $45^{\circ}$ from the central walls to the flanges. On the walls with central support, the load flux to the flanges was more intense on the lower rows. On the other hand, the behavior was inverted on the walls without central support as the flux was more intense on the upper rows. Differently from the failure mode of the first series (with support), on the second series (without support) the failure occurred abruptly and in a fragile way, as expected in a shear failure. In this case, the fissures started in a loading stage close to the maximum loads and extended through the length of the flanged walls.

Regarding the ratio of flanges/web deformation in the lower region within the levels of loading analyzed, the walls (with and without support) had similar behavior, as seen in Table [6].

The loading transfer rate from the web to the flanges in the lower region of the flanged walls with central support was approximately $77.30 \%$. For the panels without central support the transfer rate was $100,00 \%$.

\section{Conclusion}

The flanged walls with and without central support evaluated in this study had direct bonding and did not have supporting straps. The average failure load for totally supported flanged walls was $1042 \mathrm{kN}$ and for flanged walls without central support was $657 \mathrm{kN}$, being the coefficient of variation for walls with central support $21.26 \%$. A reduction in the failure load close to $37 \%$ was observed for a reduction in supporting area of approximately $45 \%$.

- It was observed that the deformations in the lower region of the central wall were low when compared to the upper region. This fact can be explained by the occurrence of load transfer from the central wall to the flanges, reducing the acting stress through the interlocking blocks.

- The elasticity modulus were relatively low when compared to the value proposed by the Brazilian norm. However, several expressions proposed in literature for its calculation have very diverging numerical results. The deformations used in this study were the ones acquired from the lower region for being a better representation of the reality.

- The experimental results showed a different behavior for flanged walls with and without central support, in particular regarding the failure mode. While a combined shear and compression failure occurred in the flanged walls with central support, a purely shear failure occurred on the flanged walls without central support.

- The failure modes were similar on the three tests in which the central walls were supported and it was clear that the failure occurred mainly on the central wall, bellow the load application point, with diagonal and staggered cracking. The failure occurred along the entire wall, passing through the blocks and the mortar joints.

- Observing the failure mode and the cracks on the panels without central support, the applied load was transferred to the flanges through the upper rows, generally speaking, on the first six to eight rows out of thirteen in total. Despite taking all the precautions during the tests, there was load eccentricity as one side deformed more than the other one.

- The estimation of the load transfer rate from the web to the flanges in this study was based on the deformation ratio of the upper region to the lower region of the panels. The average interaction rate was approximately $37.65 \%$ and $77.30 \%$ on the upper and lower regions, respectively, evidencing that the interaction occurs along the height of the wall. The load transfer rate for the panels without central support, on the other hand, was $100 \%$, as all the load was transferred to the flanges. 
- For the flanged walls examined in this study, from deformations measured at the base of the walls to load values up to $40-50 \%$ of the failure load, it is concluded that there was a transfer rate of vertical forces from the central wall to the flanges of around $70 \%$. This evidences that there was interaction between the walls and indicates that the distribution of vertical loads shall be considered in service load buildings, as in the method of walls with interaction. However, it was observed that the failure of walls with central support started at the top of the wall, where there was no vertical load transfer to the adjacent flanges yet, as observed by other authors in a number of studies, which means that in this case, the most adequate method is the independent walls one. Few specimens and a single geometry of " $\mathrm{H}$ " shaped walls were examined in this study. Therefore, further investigation is necessary in order to get definite conclusions and to recommend the use of theoretical methods to project structural masonry buildings with high strength concrete blocks.

\section{Acknowledgments}

The authors would like to acknowledge Fapemig, Capes, the Civil Engineering Department at the Universidade Federa de Viçosa and the Structures Department at the Universidade Federal de Minas Gerais for the support to execute this study, as well as the enterprise Blojad for providing the concrete blocks.

\section{References}

[1] BUILDING CODE REQUIREMENTS FOR MASONRY STRUCTURES, ACI 530-02/ ASCE 5-02/ TMS 402-02. Reported by the Masonry Standards Joint Committee, 2002.

[2] EUROPE COMITEE FOR STANDARDIZATION. Eurocode 6, EN 1996-1-1: Design of masonry structures - Part 1-1: General rules for reinforced and unreinforced masonry structures buildings. Belgium, 2005.

[3] ASSOCIAÇÃO BRASILEIRA DE NORMAS TÉCNICAS. NBR 15961-1: Alvenaria estrutural - Blocos de concreto, Parte 1: Projeto. Rio de Janeiro: ABNT, 2011. 42p.

[4] CAPUZZO NETO, VALENTIM. Estudo teórico e experimental da interação de paredes de alvenaria estrutural submetidas a ações verticais. 2000. 144f. Dissertação (Mestrado), Escola de Engenharia de São Carlos, São Paulo, 2000.

[5] ANDOLFATO, R. P. Estudo teórico e experimental da interação de paredes em edifícios de alvenaria estrutural. 2006. 232f. Tese (Doutorado), Escola de Engenharia de São Carlos, São Paulo, 2006.

[6] OLIVEIRA, L. M. F. Estudo teórico e experimental do comportamento das interfaces verticais de paredes interconectadas de alvenaria estrutural. 2014. 272f. Tese (Doutorado), Escola de Engenharia de São Carlos, São Paulo, 2014.

[7] ASSOCIAÇÃO BRASILEIRA DE NORMAS TÉCNICAS. NBR 15961-2: Alvenaria estrutural - Blocos de concreto, Parte 2: Execução e controle de obras. Rio de Janeiro: ABNT, 2011. 42p.

[8] ASSOCIAÇÃO BRASILEIRA DE NORMAS TÉCNICAS. NBR 8949: Paredes de alvenaria estrutural - Ensaio à compressão simples - Métodos de ensaio. Rio de Janeiro: ABNT, 1985. 7p.
[9] MOHAMAD, G. Mecanismos de ruptura da alvenaria de blocos à compressão. 2007. 290f. Tese (Doutorado), Escola de Engenharia, Universidade do Minho, Portugal, 2007.

[10] COMITÉ EURO-INTERNATIONAL DU BETÓN. CEB-FIP mode code 1990. Bulletin d'Information, 1990.

[11] AMERICAN CONCRETE INSTITUTE. ACI 318-11 - Building Code Requirements for Structural Concrete and Commentary. Detroit, 2011.

[12] CARVALHO, J. D. N. A contribuição de enrijecedores laterais para a ação do efeito arco na alvenaria estrutural. 2007. 284f. Tese (Doutorado), Universidade Federal de Santa Catarina, Florianópolis, 2007.

[13] ASSOCIAÇÃO BRASILEIRA DE NORMAS TÉCNICAS. NBR 12118: Blocos vazados de concreto simples para Alvenaria - Métodos de ensaio. Rio de Janeiro: ABNT, 2014. $14 \mathrm{p}$.

[14] SANTOS, W. J. Desenvolvimento de metodologia de dosagem de argamassa de revestimento e assentamento. 2014. 155f. Tese (Doutorado). Departamento de Engenharia Civil, Universidade Federal de Viçosa, Viçosa. 2014.

[15] ASSOCIAÇÃO BRASILEIRA DE NORMAS TÉCNICAS. NBR 13279: Argamassa para assentamento e revestimento de paredes e tetos - Determinação da resistência à tração na flexão e à compressão. Rio de Janeiro: ABNT, 2005. 9p.

[16] ASSOCIAÇÃO BRASILEIRA DE NORMAS TÉCNICAS. NBR 8522: Concreto - Determinação do módulo estático de elasticidade à compressão. Rio de Janeiro: ABNT, 2008, 16P.

[17] ASSOCIAÇÃO BRASILEIRA DE NORMAS TÉCNICAS. NBR 15630: Argamassa para assentamento e revestimento de paredes e tetos - Determinação do módulo de elasticidade através da propagação de onda ultra-sônica. Rio de Janeiro: ABNT, 2009. 4p.

[18] CHEMMA, T.S.S. e KLINGNER, R.E. Compressive strength of concrete masonry prisms. In: American Concrete Institute Journal. 1986. 